\title{
Astrocyte-Specific Overexpression of Nrf2 Delays Motor Pathology and Synuclein Aggregation throughout the CNS in the Alpha-Synuclein Mutant (A53T) Mouse Model
}

\author{
Li Gan, ${ }^{1}$ Marcelo R. Vargas, ${ }^{1}$ Delinda A. Johnson, ${ }^{1}$ and Jeffrey A. Johnson ${ }^{1,2,3,4}$ \\ ${ }^{1}$ School of Pharmacy, ${ }^{2}$ Waisman Center, ${ }^{3}$ Molecular and Environmental Toxicology Center, and ${ }^{4}$ Center of Neuroscience, University of Wisconsin-Madison, \\ Wisconsin, 53705
}

\begin{abstract}
Alpha synuclein (SYN) is a central player in the pathogenesis of sporadic and familial Parkinson's disease (PD). SYN aggregation and oxidative stress are associated and enhance each other's toxicity. It is unknown whether the redox-sensitive transcription factor nuclear factor erythroid 2-related factor 2 (Nrf2) plays a role against the toxicity of SYN. To examine this, mice selectively overexpressing Nrf2 in astrocytes (GFAP-Nrf2) were crossed with mice selectively expressing human mutant SYN (hSYN ${ }^{\mathrm{A} 53 \mathrm{~T}}$ ) in neurons. Increased astrocytic Nrf2 delayed the onset and extended the life span of the hSYN ${ }^{\mathrm{A} 53 \mathrm{~T}}$ mice. This correlated with increased motor neuron survival, reduced oxidative stress, and attenuated gliosis in the spinal cord, as well as a dramatic decrease in total hSYN ${ }^{\mathrm{A} 53 \mathrm{~T}}$ and phosphorylated (Ser129) $\mathrm{hSYN}^{\mathrm{A} 33 \mathrm{~T}}$ in Triton-insoluble aggregates. Furthermore, Nrf2 in astrocytes delayed chaperone-mediated autophagy and macroautophagy dysfunction observed in the hSYN ${ }^{\mathrm{A} 33 \mathrm{~T}}$ mice. Our data suggest that Nrf2 in astrocytes provides neuroprotection against hSYN ${ }^{\mathrm{A} 53 \mathrm{~T}}$ mediated toxicity by promoting the degradation of hSYN ${ }^{\mathrm{A} 53 \mathrm{~T}}$ through the autophagy-lysosome pathway in vivo. Thus, activation of the Nrf2 pathway in astrocytes is a potential target to develop therapeutic strategies for treating pathologic synucleinopathies including PD.
\end{abstract}

\section{Introduction}

Parkinson's Disease (PD) is the second most common neurodegenerative disorder, and is characterized by dopaminergic neuron loss in substantial nigra pars compacta (SNpc). Multiple mechanisms contribute to PD pathogenesis with a clear involvement of oxidative stress and mitochondria dysfunction in disease progression. Recently, accumulating evidence has demonstrated that misfolded proteins and inclusions contribute to the pathology of familial and sporadic PD. Alpha synuclein (SYN) is the main component of these inclusions (Spillantini et al., 1997; Irizarry et al., 1998). Missense mutations (A53T, A30P, E64K) in SYN are associated with autosomal dominant PD (Polymeropoulos et al., 1997; Krüger et al., 1998; Singleton et al., 2003). SYN is natively unfolded but is prone to form fibrils under disease conditions. SYN and phospho-SYN-positive aggregates have been observed in the familial PD patients (Braak et al., 2003; Tamura et al., 2012). Increasing evidence implicates the autophagy-lysosome pathway (ALP) in mediating the clearance

Received June 25, 2012; revised Sept. 25, 2012; accepted 0ct. 18, 2012.

Author contributions: L.G. and J.A.J. designed research; L.G., M.R.V., and D.A.J. performed research; M.R.V. and D.A.J. contributed unpublished reagents/analytic tools; L.G. and J.A.J. analyzed data; L.G. and J.A.J. wrote the paper.

This work was supported by the grant from the National Institute of Environmental Health Sciences (NIEHS ES10042). We thank Randall Massey from Medical School Electron Microscope Facility for his technical assistance. The authors declare no competing financial interests.

Correspondence should be addressed to Professor Jeffrey A. Johnson, School of Pharmacy, Waisman Center, Molecular and Environmental Toxicology Center, Center of Neuroscience, University of Wisconsin-Madison, WI, 53705. E-mail: jajohnson@pharmacy.wisc.edu.

M. R. Vargas' present address: Cell and Molecular Pharmacology, Medical University of South Carolina, Charleston, SC, 29425.

DOI:10.1523/JNEUROSCI.3049-12.2012

Copyright $\odot 2012$ the authors $\quad 0270-6474 / 12 / 3217775-13 \$ 15.00 / 0$ of misfolded proteins and impaired organelles in neurodegenerative diseases. A recent report suggests that SYN can be degraded through the ubiquitin-proteasome system (UPS) under normal conditions and ALP is recruited under extra SYN burden (Ebrahimi-Fakhari et al., 2011).

Chaperone-mediated autophagy (CMA) has been shown to clear wild-type SYN. SYN binds with heat shock cognate 70 (Hsc70) that then binds to the lysosomal transmembrane protein Lamp2a facilitating subsequent lysosomal degradation. SYN mutants actually bind to Lamp2a with higher affinity blocking their own degradation as well as other CMA substrates (Cuervo et al., 2004). Macroautophagy results in the formation of autophagic vacuoles with trapped misfolded proteins and damaged organelles. When CMA is impaired, macroautophagy is activated to compensate for reduced protein clearance (Honegger et al., 2006). SYN can also be degraded through macroautophagy in neuronal cells in vitro (Vogiatzi et al., 2008) and overexpression of SYN impairs macroautophagy (Winslow et al., 2010).

Nuclear factor erythroid 2-related factor 2 (Nrf2) is an antioxidant transcription factor; under basal conditions Nrf2 is associated with actin-bound Keap1 in cytoplasm. Keap1 targets Nrf2 to the Cullin3 E3 ligase complex for ubiquitination and subsequent degradation by the UPS. Oxidative stress and/or exposure to electrophilic compounds cause the release and nuclear translocation of Nrf2. In complex with small Maf proteins Nrf2 binds with the antioxidant-responsive elements (ARE) inducing transcriptional activation of downstream genes encoding phase II detoxifying enzymes and antioxidants (Itoh et al., 1997; Motohashi et al., 2002). Previous studies demonstrate that astrocytespecific overexpression of $\mathrm{Nrf2}$ reduces chemical-mediated 
neurotoxicity modeling PD and Huntington's disease (Chen et al., 2009; Calkins et al., 2010), as well as genetically induced motor neuron degeneration in models of amyotrophic lateral sclerosis (Vargas et al., 2008).

Reports indicate that oxidative stress can enhance SYN toxicity, induce autophagic cell death, and cause abnormal modification of proteins involved in autophagy (Zheng et al., 2009; Chew et al., 2011). Recent work shows that Nrf2 deficiency can exacerbate SYN aggregation in mice using an adeno-associated viral vector-expressing human SYN (Lastres-Becker et al., 2012). In Drosophila overexpressing SYN, genetically increasing Nrf2 restored locomotor activity (Barone et al., 2011). However, the effect of Nrf2 activation on synucleinopathy and SYN clearance by ALP in rodent models has not been examined. We hypothesized that overexpression of Nrf2 will protect against hSYN ${ }^{\mathrm{A} 53 \mathrm{~T}}$ toxicity. This was examined by crossing GFAP-Nrf2 mice with Thyl-hSYN ${ }^{\mathrm{A} 53 \mathrm{~T}}$ mice.

\section{Materials and Methods}

Mouse strains. Thyl-hSYN ${ }^{\mathrm{A} 53 \mathrm{~T}}$ transgenic mice were purchased from The Jackson Laboratory [Strain Name: B6.Cg-Tg(THY1-SNCA*A53T) M53Sud/J; Stock Number: 008135]. The line was created and characterized by Dr. Thomas C. Südhof s laboratory (Chandra et al., 2005; Gallardo et al., 2008). The ARE-hPAP transgenic reporter mouse line was created using the 51 bp rat NADPH:quinone oxidoreductase (NQO1) promoter containing the core ARE sequence (ARE-hPAP) (Johnson et al., 2002). hSYN ${ }^{\text {A53T }}$ mice were bred with ARE-hPAP mice to generate $\mathrm{hSYN}{ }^{\mathrm{A} 53 \mathrm{~T}}$ positive/negative and ARE-hPAP-positive mice $\left[\operatorname{hSYN}^{\mathrm{A} 53 \mathrm{~T}}(+) / \mathrm{hPAP}(+), \mathrm{hSYN}^{\mathrm{A} 53 \mathrm{~T}}(-) /\right.$ $\mathrm{hPAP}(+)$ ]. Transgenic mice with astrocyte-specific overexpression of $\mathrm{Nrf} 2$ were made under the control of the human glial fibrillary acidic protein (GFAP) promoter (GFAP-Nrf2) (Vargas et al., 2008). hSYN ${ }^{\text {A53T }}$ mice were bred with GFAP-Nrf2 mice to generate hSYN ${ }^{\text {A53T }}(+) /$ GFAP-Nrf2 $(+)$ double transgenic mice $[\mathrm{AN}(+/+)]$, littermate wild-type hSYN ${ }^{\mathrm{A} 53 \mathrm{~T}}(-) / \mathrm{GFAP}-$ $\mathrm{Nrf2}(-)$ mice $[\mathrm{AN}(-/-)]$, littermate hSYN ${ }^{\mathrm{A} 53 \mathrm{~T}}(+) / \mathrm{GFAP}-\mathrm{Nrf2}(-)$ mice $[\mathrm{AN}(+/-)]$, and littermate $\mathrm{hSYN}^{\mathrm{A} 53 \mathrm{~T}}(-) / \operatorname{GFAP}-\mathrm{Nrf} 2(+)$ mice $[\mathrm{AN}(-/+)]$. hSYN $^{\text {A53T }}$ heterozygous mice were maintained on C57BL/6J background. GFAP-Nrf2 mice were maintained on B6/SJL mice (The Jackson Laboratory). Thus, these crossbred mice were on a mixed B6/SJL background. Both male and female mice were used. End stage was determined by the inability of the mouse to lift itself within $20 \mathrm{~s}$ when placed on its both sides. The disease onset was determined by the peak body weight. Mice were weighed once a week and group housed with food and water ad libitum and with a $12 \mathrm{~h}$ light/dark cycle. All animal procedures were approved by the University of Wisconsin-Madison Institutional Animal Care and Use Committee. All experiments were conducted according to the National Institutes of Health Guide for the Care and Use of Laboratory Animals.

Western blotting. The procedures were performed as previously described (Gan et al., 2010). For detergent-soluble and -insoluble fractions: tissues were lysed in lysis buffer ( $50 \mathrm{~mm}$ Tris- $\mathrm{HCl}, \mathrm{pH} 7.4,150 \mathrm{~mm} \mathrm{NaCl}$, $2 \mathrm{~mm}$ EDTA, $1 \mathrm{~mm}$ dithiothreitol, $1 \mathrm{~mm} \mathrm{Na}_{3} \mathrm{VO}_{4}, 1 \mathrm{~mm} \mathrm{NaF}$, and protease inhibitor mixture tablet from Roche) containing 1\% Triton X-100 (Buffer A) as the ratio of 1:10 ( $1 \mathrm{mg}$ of tissue: $10 \mu \mathrm{l}$ of lysis buffer), and whole lysates were centrifuged at $100,000 \mathrm{~g}, 30 \mathrm{~min}$ at $4^{\circ} \mathrm{C}$. The supernatants were taken as Triton-soluble fractions. The pellets were rinsed with Buffer A five times, and then resuspended in lysis buffer containing Buffer A, $1 \%$ SDS and $0.5 \%$ sodium deoxycholate. After sonication and brief spin down, the lysates were taken as Triton-insoluble (SDS-soluble) fractions. For LC3 Western blot, tissues were directly lysed in lysis buffer containing $1 \%$ SDS. The dilutions for primary antibodies: $\alpha$ SYN (4B12) 1:10,000 (Abcam), Ser ${ }^{129}$-phospho- $\alpha$ SYN 1:2000 (Abcam), CathepsinD (CatD), 1:2000 (Santa Cruz Biotechnology), NQO1 1:1000 (Abcam), $\beta$-actin 1:5000 (Abcam), tubulin 1:5000 (hybridoma, University of Iowa), GADPH 1:3000 (Cell Signaling Technology), HSC70 1:3000 (Epitomics), Lamp2a 1:1000 (Abcam), microtuble-associated protein light chain 3 (LC3) 1:2000 (Cell Signaling Technology), ubiquitin 1:1000 (Cell Signaling Technology), sequestosome 1 (SQSTM1, P62) 1:4000 (Abnova), myocyte enhancer factor 2D (MEF2D) 1:2000 (BD Biosci- ences), glutamate-cysteine ligase catalytic subunit (GCLc) and modifier subunit (GCLm) 1:10000 (provided by Dr. Terry Kavanagh, University of Washington, Seattle, WA).

Immunofluorescence and histochemistry. Mice were perfused with PBS followed by $4 \%$ paraformaldehyde (PFA). Tissues were postfixed for $2 \mathrm{~h}$ at $4^{\circ} \mathrm{C}$ and cryoprotected in $30 \%$ sucrose in PBS at $4^{\circ} \mathrm{C}$ until sinking to the bottom. Coronal sections were prepared using a cryostat (Leica). Sections were permeabilized and blocked with $10 \%$ goat serum, $1 \%$ bovine serum albumin (BSA), and $0.36 \%$ Triton X-100 in PBS for $1 \mathrm{~h}$ at room temperature (RT), then incubated with primary antibodies diluted in $10 \%$ goat serum, $1 \% \mathrm{BSA}$ in $\mathrm{PBS}$ at $4^{\circ} \mathrm{C}$ overnight. Appropriate IgG was used for controls. The following day, sections were incubated with secondary antibodies diluted in the same solution for $1 \mathrm{~h}$ at RT after intensive wash. For nuclear DNA staining, slides were incubated in $1 \mu \mathrm{g} / \mathrm{ml}$ Hoechst 33258 in PBS for 5 min. Primary antibodies were used at the following dilutions: $\alpha$ SYN (LB509) 1:1000 (Abcam), Ser ${ }^{129}$-phospho- $\alpha$ SYN 1:500 (Abcam), $\beta$-III-tubulin 1:1000 (Abcam), GFAP 1:1000 (Dako), ionized calcium binding adaptor molecular (IBA1) 1:600 (Wako), 4-hydroxynonenal (HNE) 1:500 (Abcam). MEF2D 1:500 (BD Sciences), p62 1:500 (Abnova), and ubiquitin (UV-1) 1:250 (Life Science). Secondary antibodies were using Alex Fluor 488 and 594 (Invitrogen) with dilution of 1:1000. For motor neuron count, cresyl violet acetate staining was performed. Every sixth section $(10 \mu \mathrm{m})$ was stained and a total of 32-40 sections were counted from each mouse using ImageJ.

Real-time PCR. mRNA extraction, reverse transcription, real-time PCR performance and data analysis were conducted as previously described (Gan et al., 2010). IBA1 primers: 5'-CGAATGCTGGAGAA ACTTGG-3' ' 5'-AGAGTAGCTGAACGTCTCCT-3'. The rest of primer sequences were referenced (Johnson et al., 2010).

Glutathione measurement. To determine the levels of reduced (GSH) and oxidized (GSSG) glutathione, it was measured by normal-phase (ion exchange) HPLC (Fariss and Reed, 1987). Supernatants were alkylated with iodoacetic acid followed by derivatization with 1-flouro-2,4, dinitrobenzene. The $S$-carboxymethyl- $N$-dinitrophenyl-derivatized samples were then loaded onto a 3-aminopropyl-Spherisorb column (Waters Corporation) and separated by a sodium acetate/methanol gradient using a Shimadzu Prominence HPLC system. Resolved GSH and GSSG analyte was detected at $365 \mathrm{~nm}$ using a Shimadzu Prominence SPD-20A UV/Vis detector. GSH and GSSG concentrations in the samples were determined by reference GSH and GSSG standard curves included in each run and subsequently normalized to respective tissue protein concentrations.

Electron microscopy. Mice were perfused with PBS followed by $4 \%$ PFA, and the spinal cord lumbar area was dissected and postfixed in $2 \%$ glutaraldehyde and 2\% PFA in PBS for overnight. The primary fixed samples were rinsed five times for $5 \mathrm{~min}$ in PBS, and postfixed in $1 \%$ osmium tetroxide, $1 \%$ potassium ferrocyanide in PBS for $1 \mathrm{~h}$ at RT, and then rinsed in PBS as before. After dehydration, samples were infiltrated in the mixtures of PolyBed 812 (Polysciences) and propylene oxide with increasing concentrations. The samples were sectioned on a Leica EM UC6 ultramicrotome at $90 \mathrm{~nm}$, and collected on $\mathrm{Cu}$, pioloform-coated $2 \times 1$ oval slot grids (EMS) followed with poststaining in uranyl acetate and lead citrate. The sections from different genotypes of mice were viewed at $80 \mathrm{kV}$ on a Philips CM120 transmission electron microscope, equipped with MegaView III camera (Olympus Soft Imaging System).

Statistical analysis. All data are represented as mean \pm SEM. Statistical analysis was performed using one-way ANOVA followed by NewmanKeuls multiple paired comparisons (GraphPad prism 4). The KaplanMeier survival curves were compared by log rank test. Statistical significance was claimed as if $p<0.05$.

\section{Results}

Endogenous Nrf2-ARE pathway is activated in hSYN $^{\text {A53T }}$ mice

The hSYN ${ }^{\text {A53T }}$ mice used in these studies show motor dysfunction, become paralyzed, and die between 6 and 10 months of age (Chandra et al., 2005; Gallardo et al., 2008). To test if the endog- 

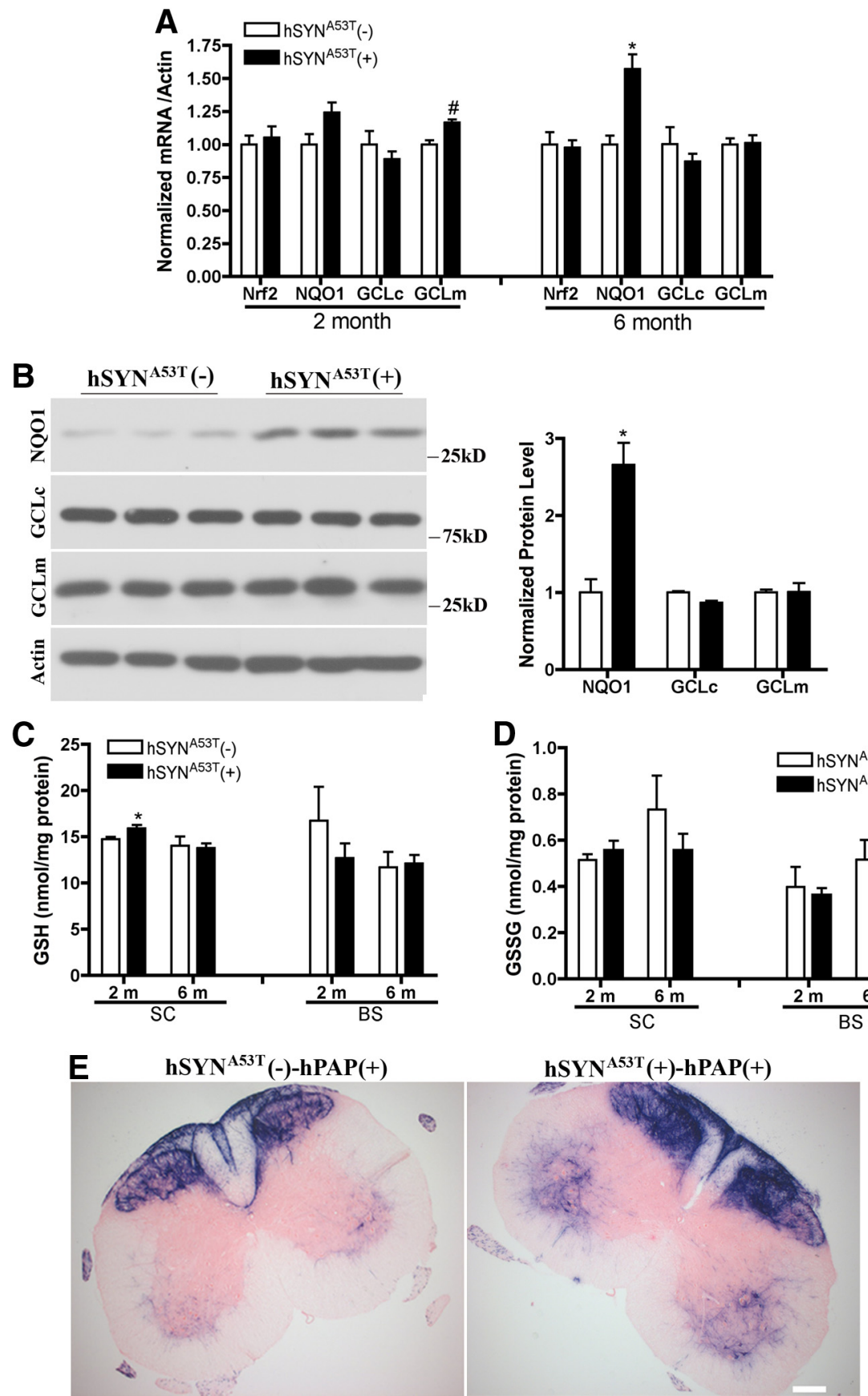

Figure 1. Endogenous Nrf2-ARE pathway is activated in $\mathrm{hSYN}{ }^{\mathrm{A} 33 \mathrm{~T}}$ transgenic mice. $A$, mRNA levels of Nrf2 and its regulated genes in spinal cord of 2 - and 6-month-old nonsymptomatic hSYN ${ }^{\mathrm{A} 33 \mathrm{~T}}$ mice. $n=4 .{ }^{*} p<0.001,{ }^{\#} p<0.05, \mathrm{hSYN}^{\mathrm{A} 53 \mathrm{~T}}(+)$ versus hSYN $^{\text {A53T }}(-)$. $\boldsymbol{B}$, Western blots of NQ01, GCLC, and GCLm for 6-month-old hSYN ${ }^{\text {A53T }}$ mice. ${ }^{*} p<0.001$, hSYN ${ }^{A 53 T}(+)$ versus $\mathrm{hSYN}^{\mathrm{A} 33 \mathrm{~T}}(-) . n=3 . \boldsymbol{C}, \boldsymbol{D}, \mathrm{GSH}$ and GSSG levels in spinal cord and brainstem of 2 - and 6 -month-old nonsymptomatic hSYN ${ }^{\mathrm{A} 53 \mathrm{~T}}$ mice. $n=3-5 .{ }^{*} p<0.05$, hSYN ${ }^{A 53 T}(+)$ versus $\mathrm{SSYN}^{\mathrm{A} 53 \mathrm{~T}}(-) . \boldsymbol{E}$, hPAP activity represented by histochemical staining in spinal cord of nonsymptomatic 6-month-old hSYN ${ }^{\text {A53T }}$ mice; $n=3$. Scale bar, $500 \mu \mathrm{m}$.

enous Nrf2-ARE pathway was activated in hSYN ${ }^{\text {A53T }}$ mice and involved in the pathology of this mouse model, mRNA levels of Nrf2 and its regulated genes were measured at 2 and 6 months of age in nonsymptomatic mice. Compared with age-matched hSYN $^{\mathrm{A} 53 \mathrm{~T}}$-negative mice, NQO1 increased in spinal cord at 6 months. GCLm increased significantly at 2 months but not at 6 months (Fig. 1A). Correlating with mRNA data, the protein level of NQO1 increased significantly in spinal cord at 6 months, and there were no changes for GCLc and GCLm (Fig. 1B). GSH levels were slightly increased in the spinal cord of 2-month-old mice, but not 6-monthold mice (Fig. 1C). There was no significant change of GSSG in spinal cord and brainstem at both ages (Fig. 1D). $\mathrm{hSYN}^{\mathrm{A} 53 \mathrm{~T}}$ mice were also bred with AREhPAP mice and hPAP activity was examined through histochemical staining (Fig. $1 E)$. Increased intensity for hPAP staining was observed in ventral horn of spinal cord of 6-month-old mice (Fig. 1E) but not 2-month-old mice (data not shown). More modest increases in hPAP histochemistry were observed in substantia nigra, amygdala, and brainstem (data not shown).

\section{Astrocyte-specific overexpression of Nrf2 extends the life span of hSYN ${ }^{\text {A53T }}$ mice and increases motor neuron survival}

To enhance this modest endogenous Nrf2 activation, we crossbred hSYN ${ }^{\mathrm{A} 53 \mathrm{~T}}$ mice with GFAP-Nrf2 transgenic mice to determine whether astrocytic overexpression of Nrf2 could alleviate pathology in the hSYN $^{\text {A53T }}$ mice. There was a dramatic and significant extension of life span by $65.5 \mathrm{~d}$ in the double transgenic mice (Fig. 2A). The disease onset was also delayed by $63.5 \mathrm{~d}$ (Fig. 2B). No significant difference was observed in disease progression between hSYN ${ }^{\text {A53T }}$ mice and double transgenic mice (Fig. 2C). Based on the onset data, there appeared to be two different subsets of hSYN ${ }^{\mathrm{A} 53 \mathrm{~T}}[\mathrm{AN}(+/-)]$ mice: early $(<200 \mathrm{~d})$ and late $(>200 \mathrm{~d})$ onset mice. Thus, we divided these mice into two groups based on onset and reanalyzed the data. For the early onset group, Nrf2 overexpression extended the life span and delayed disease onset and progression significantly by $73 \mathrm{~d}, 59 \mathrm{~d}$, and $6.2 \mathrm{~d}$, respectively (Fig. $2 D-F$ ). For the late onset group the extension in survival (26 d) and delay in onset (13 d) were not statistically significant (Fig. 2G-I). Subsequent biochemical and histochemical analysis was performed on $\sim 6$-monthold mice.

Another cohort of mice was harvested at 6 months of age and the number of motor neurons in the lumbar spinal cord was quantified blindly (Fig. 2J). Motor neuron numbers in asymptomatic $\mathrm{hSYN}^{\mathrm{A} 53 \mathrm{~T}}(+) / \operatorname{GFAP}-\mathrm{Nrf2}(-)$ mice $[\mathrm{AN}(+/-)]$ were not significantly different from control $\operatorname{hSYN}^{\mathrm{A} 53 \mathrm{~T}}(-) / \operatorname{GFAP}-\mathrm{Nrf2}(-)$ mice $[\mathrm{AN}(-/-)]$ (Fig. 2D). However, the degree of variability within this group does suggest that the range of motor neuron loss between mice is large as would be expected in asymptomatic mice with such a large range in life span. In contrast, symptomatic mice $\left[\mathrm{AN}(+/-)^{*}\right]$ had a consistent and significant loss of $80 \%$ of their motor neurons. This loss was reversed in the double transgenic $\operatorname{hSYN}^{\mathrm{A} 53 \mathrm{~T}}(+) /$ 

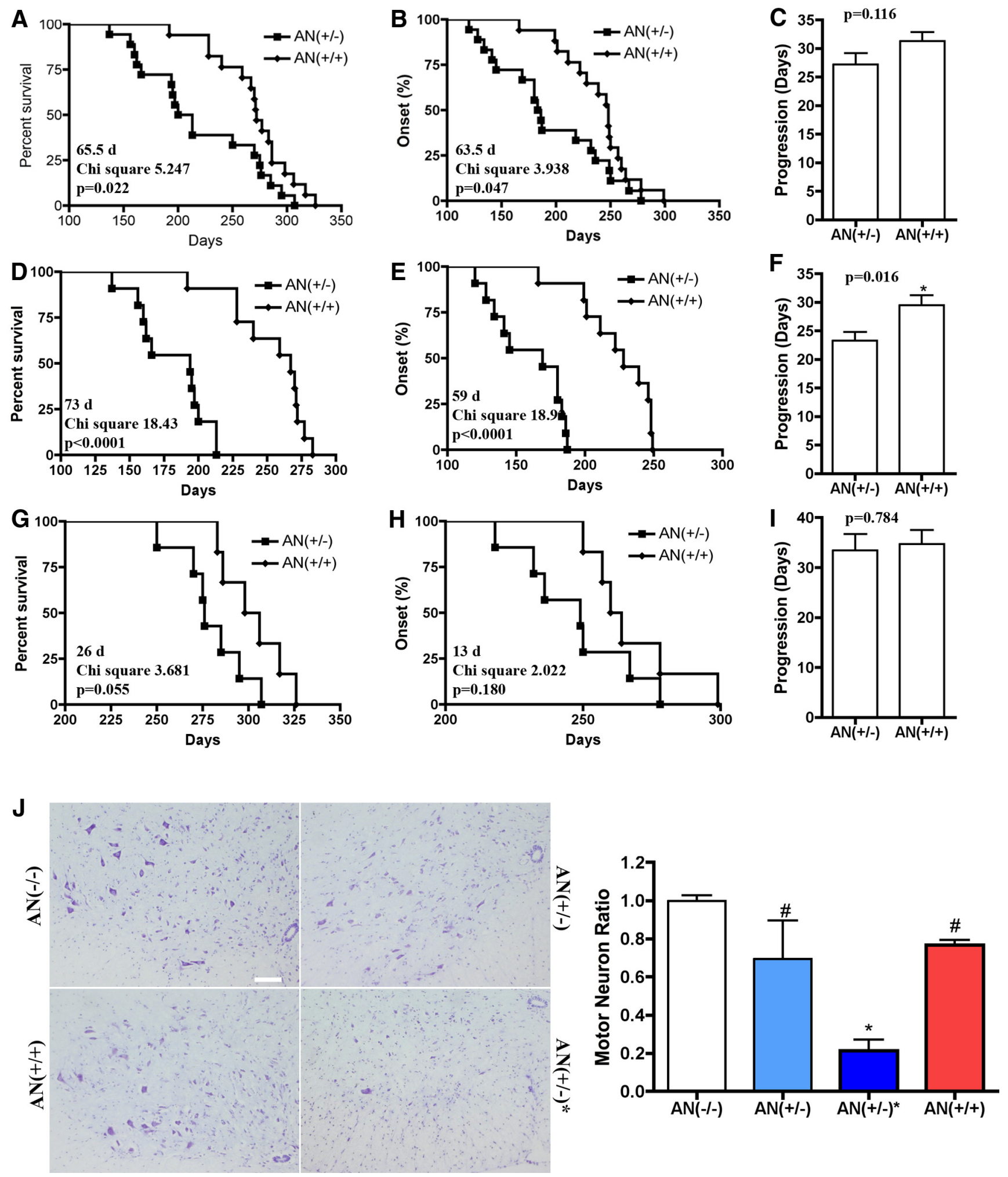

Figure 2. Overexpression of $\mathrm{Nrf2}$ in astrocytes extends the life span of $\mathrm{hSYN}{ }^{\mathrm{A} 33 \mathrm{~T}}$ transgenic mice and increases motor neuron survival in spinal cord. $A$, Nrf2 overexpression in astrocytes increased the median survival from $206.5 \mathrm{~d}$ in hSYN ${ }^{\text {A53T }}$ mice $[A N(+/-)](n=18)$ to $272.0 \mathrm{~d}$ in hSYN ${ }^{A 53 T} /$ GFAP-Nrf2 double transgenic mice $[A N(+/+)](n=17) . p=0.0220, \chi^{2}=5.247 . B$, Nrf2 overexpression delayed disease onset from $184.5 \mathrm{~d}$ in $\mathrm{AN}(+/-)$ mice $(n=18)$ to $248.0 \mathrm{~d}$ in $\mathrm{AN}(+/+)$ mice $(n=17) . p=0.047, \chi^{2}=3.938$. C, No difference was observed in disease progression between $\mathrm{AN}(+/-)$ mice $(27.22 \pm 1.93, n=18)$ and $\mathrm{AN}(+/+)$ mice $(31.29 \pm 1.60, n=17)$. Values are the mean \pm SEM. $\boldsymbol{D}-\boldsymbol{F}$, Early onset $(<200 \mathrm{~d})$ cohort. $\boldsymbol{D}$, The median survival of 194.0 $\operatorname{din} \mathrm{AN}(+/-)$ mice $(n=11)$ was prolonged to $267.0 \mathrm{~d}$ in AN $(+/+)$ double transgenic mice $(n=11) . p<0.0001, \chi^{2}=18.43$. E, The disease onset of $169.0 \mathrm{~d}$ in $\mathrm{AN}(+/-)$ mice $(n=11)$ was delayed to $228.0 \mathrm{~d}$ in $\mathrm{AN}(+/+)$ double transgenic mice $(n=11) . p<0.0001, \chi^{2}=18.92 . \boldsymbol{F}$, The disease progression of $23.27 \pm 1.53 \mathrm{~d}$ in AN $(+/-)$ mice $(n=11)$ was significantly extended to $29.45 \pm 1.77 \mathrm{~d}$ in AN $(+/+)$ double transgenic mice $(n=11) . p=0.016$. Values are the mean \pm SEM. $\mathbf{G}-\mathbf{I}$, Late onset $(>200 \mathrm{~d})$ cohort. $\mathbf{G}$, The median survival of $276.0 \mathrm{~d}$ in AN $(+/-)$ mice $(n=7)$ was prolonged to $302.0 \mathrm{~d}$ in $\mathrm{AN}(+/+)$ double transgenic mice $(n=6) . p=0.055, \chi^{2}=3.681$. $\boldsymbol{H}$, The disease onset of $249.0 \mathrm{~d}$ in $\mathrm{AN}(+/-)$ mice $(n=7)$ was delayed to $262.0 \mathrm{~d}$ in $\operatorname{AN}(+/+)$ double transgenic mice $(n=6) . p=0.180, \chi^{2}=2.022 . I$, The disease progression in AN $(+/-)$ mice $(33.43 \pm 3.25 \mathrm{~d}, n=7)$ and AN $(+/+)$ double transgenic mice $(34.67 \pm 2.86 \mathrm{~d}$, $n=6$ ) was similar; $p=0.784$. Values are the mean \pm SEM. J, Estimated number of motor neuron in the ventral horn of spinal cord of 6-month-old hSYN ${ }^{\text {A53T }}$ transgenic (Figure legend continues.) 
A

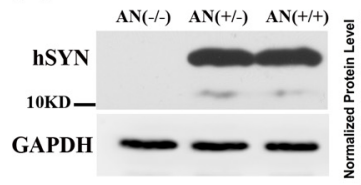

C $\left.{ }^{{ }^{2}}{ }^{1.2}\right] \quad$ Triton soluble
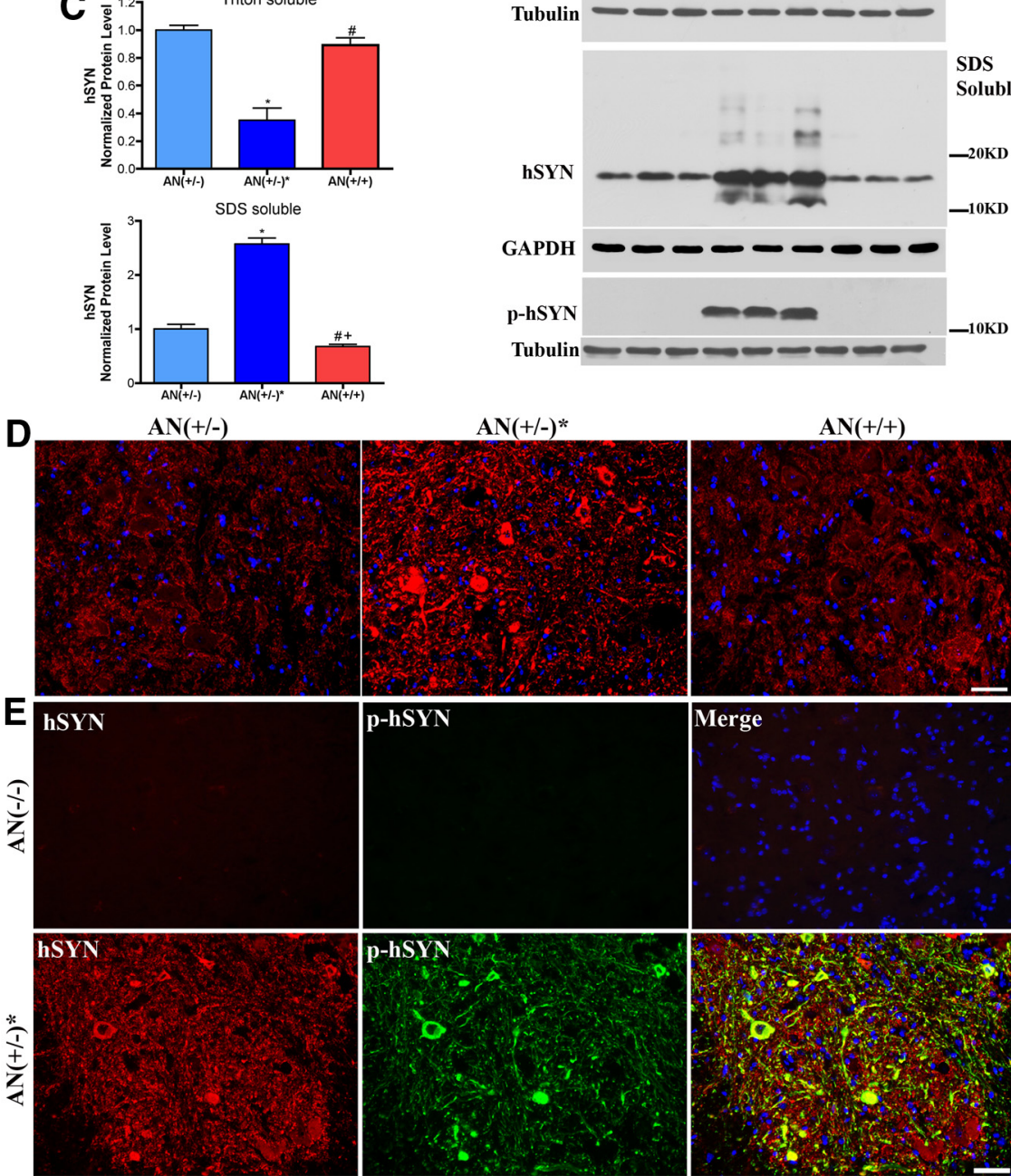

Figure 3. Overexpression of Nrf2 in astrocytes decreases $h S Y N^{\mathrm{A} 53 \mathrm{~T}}$ and $\mathrm{p}-\mathrm{hSYN}{ }^{\mathrm{A} 53 \mathrm{~T}}$ aggregates in spinal cord. $\boldsymbol{A}$, Western blotting of hSYN ${ }^{\mathrm{A} 33 \mathrm{~T}}$ for Triton-soluble fractions from spinal cords of 2-month-old hSYN ${ }^{\mathrm{A5} 3 \mathrm{~T}}$ mice and age-matched littermates Quantification is shown in the right, mean \pm SEM; $n=4$. B. Western blotting of hSYN ${ }^{\text {A53T }}$ and $p-h S Y N{ }^{A 53 T}$ in Triton-soluble and -insoluble fractions (SDS-soluble fractions) from the spinal cord of 6-month-old hSYN ${ }^{A 53 T}$ mice and age-matched littermates. $\boldsymbol{C}$, Quantificative data for hSYN ${ }^{\mathrm{A} 53 \mathrm{~T}}$ protein level, mean $\pm \mathrm{SEM} ; n=3 .{ }^{*} p<0.001, \mathrm{AN}(+/-)^{*}$ versus AN $(-/-)$; ${ }^{\#} p<0.001$, $\mathrm{AN}(+/+)$ versus $\mathrm{AN}(+/-)^{*} ;{ }^{+} p<0.05, \mathrm{AN}(+/+)$ versus $\mathrm{AN}(+/-) . \boldsymbol{D}-\boldsymbol{E}$, Fluorescent immunostaining of $h \mathrm{hYN}^{\mathrm{A} 53 \mathrm{~T}}$ and p-hSYN ${ }^{A 53 T}$ aggregates with $80 \%$ formic acid pretreatment in spinal cord of 6-month-old mice. $\boldsymbol{D}$, Staining for hSYN ${ }^{\mathrm{A} 33 \mathrm{~T}}$ in asymptomatic, symptomatic, and double transgenic mice. $\boldsymbol{E}$, Colocalization of hSYN ${ }^{\mathrm{A} 53 \mathrm{~T}}$ and $\mathrm{p}-\mathrm{SYN}{ }^{\mathrm{A} 53 \mathrm{~T}}$ in symptomatic mice; $n=$ 3. Scale bars: $50 \mu \mathrm{m}$.

GFAP-Nrf2 $(+)[\mathrm{AN}(+/+)]$. Nrf2 overexpression does not affect motor neuron development because there was no difference in motor neuron numbers in GFAP-Nrf2 mice compared with wildtype control mice. (Vargas et al., 2008).

$\leftarrow$

(Figure legend continued.) mice without symptoms $[\mathrm{AN}(+/-)]$ and with symptoms $\left[\mathrm{AN}(+/-)^{*}\right]$ along with age-matched littermate wild-type controls $[\mathrm{AN}(-/-)]$. Left, Representative images with Nissl staining. Scale bar, $100 \mu \mathrm{m}$. The quantified data are shown on the right. Mean $\pm \mathrm{SEM} ; n=3 .{ }^{*} p<0.01, \mathrm{AN}(+/-)^{*}$ versus $\mathrm{AN}(-/-){ }^{\#} p<0.05, \mathrm{AN}(+/+)$, $\mathrm{AN}(+/-)$ versus $\mathrm{AN}(+/-)^{*}$.
Nrf2 decreases $\alpha$-synuclein aggregates, gliosis, and oxidative stress in hSYN ${ }^{\text {A53T }}$ mice

To ensure that the observed changes in life span and onset were not due to Nrf2mediated downregulation of the hSYN ${ }^{\mathrm{A} 53 \mathrm{~T}}$ transgene levels in the mice, a Western blot was performed on 2-month-old spinal cord extracts demonstrating that hSYN ${ }^{\mathrm{A} 53 \mathrm{~T}}$ levels were not affected by Nrf2 overexpression in astrocytes (Fig. 3A). Compared with 6-month-old mice without symptoms $[\mathrm{AN}(+/-)]$, the amount of hSYN ${ }^{\mathrm{A} 33 \mathrm{~T}}$ in the Triton-soluble fraction from spinal cord decreased $60 \%$ in age-matched symptomatic mice $\left[\mathrm{AN}(+/-)^{*}\right]$ (Fig. $\left.3 B, C\right)$. This was accompanied by a significant increase in hSYN ${ }^{\mathrm{A} 53 \mathrm{~T}}$ in the Triton-insoluble/SDSsoluble fraction. This movement of hSYN ${ }^{\mathrm{A} 53 \mathrm{~T}}$ into Triton-insoluble/SDS-soluble aggregates was completely reversed by overexpression of Nrf2 in astrocytes $[\mathrm{AN}(+/+)]$ (Fig. 3B,C). Similar changes were observed for phosphorylated (Ser129) hSYN ${ }^{\text {A53T }}$ (phSYN $^{\mathrm{A} 53 \mathrm{~T}}$ ) in Triton-soluble and Tritoninsoluble/SDS-soluble fractions (Fig. 3B). Fluorescent staining of hSYN ${ }^{\mathrm{A} 53 \mathrm{~T}}$ on formic acid pretreated sections correlates the results from Western blotting showing a dramatic increase in hSYN ${ }^{\mathrm{A} 53 \mathrm{~T}}$ aggregates (Fig. $3 D)$. Again, this change was completely reversed by GFAP-Nrf2 $[\mathrm{AN}(+/+)]$ (Fig. $3 D$ ). In addition, there was a clear colocalization of hSYN ${ }^{\mathrm{A} 33 \mathrm{~T}}$ and $\mathrm{p}-\mathrm{hSYN}{ }^{\mathrm{A} 53 \mathrm{~T}}$ in the aggregates (Fig. 3E). This is consistent with the previous observation that the main form of hSYN ${ }^{\mathrm{A} 53 \mathrm{~T}}$ in inclusions is the phosphorylated form of hSYN ${ }^{\mathrm{A53T}}$ (Fujiwara et al., 2002; Anderson et al., 2006).

Similar changes for $\mathrm{p}-\mathrm{hSYN}{ }^{\mathrm{A} 53 \mathrm{~T}}$ were seen throughout the brain. Fluorescent immunostaining showed increased density of p-hSYN ${ }^{\mathrm{A} 53 \mathrm{~T}}$ in motor cortex, middle brain, and brainstem in symptomatic hSYN $^{\mathrm{A} 53 \mathrm{~T}}$ mice and not in double transgenic mice (Fig. 4A,B). There was also a slightly increased density of p-hSYN ${ }^{\mathrm{A} 53 \mathrm{~T}}$ in striatum and cerebellum of symptomatic hSYN ${ }^{\mathrm{A} 53 \mathrm{~T}}$ mice (data not shown). There was a striking increase of $\mathrm{p}-\mathrm{hSYN} \mathrm{N}^{\mathrm{A} 33 \mathrm{~T}}$ staining in $\mathrm{SN}$, especially in the pars reticulata (SNpr) (Fig. 4B, middle). There was a modest colocalization of p-hSYN ${ }^{\mathrm{A} 53 \mathrm{~T}}$ and tyrosine hydrolase $(\mathrm{TH})$ in SNpc (Fig. 4C,D). This is probably due to the low level of SYN expression driven by Thyl promoter in dopaminergic neurons (van der Putten et al., 2000; Fernagut and Chesselet, 2004). The GFAP-Nrf2 mice completely prevented or significantly reduced the $\mathrm{p}-\mathrm{hSYN}{ }^{\mathrm{A} 53 \mathrm{~T}}$ accumulation throughout these different brain regions (Fig. $4 A-C$ ).

Nrf2 overexpression in astrocytes also reduced astrogliosis and microgliosis in symptomatic hSYN ${ }^{\mathrm{A} 53 \mathrm{~T}}$ mice, as determined by GFAP and IBA1 immunofluorescent staining and mRNA levels (Fig. $5 A-C$ ). NADPH oxidase, a potential generator of reactive 
A

MI

$\mathrm{AN}(+/-)$ MB BS

B

$\mathbf{A N}(+/-)$

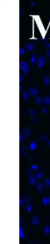

SNp

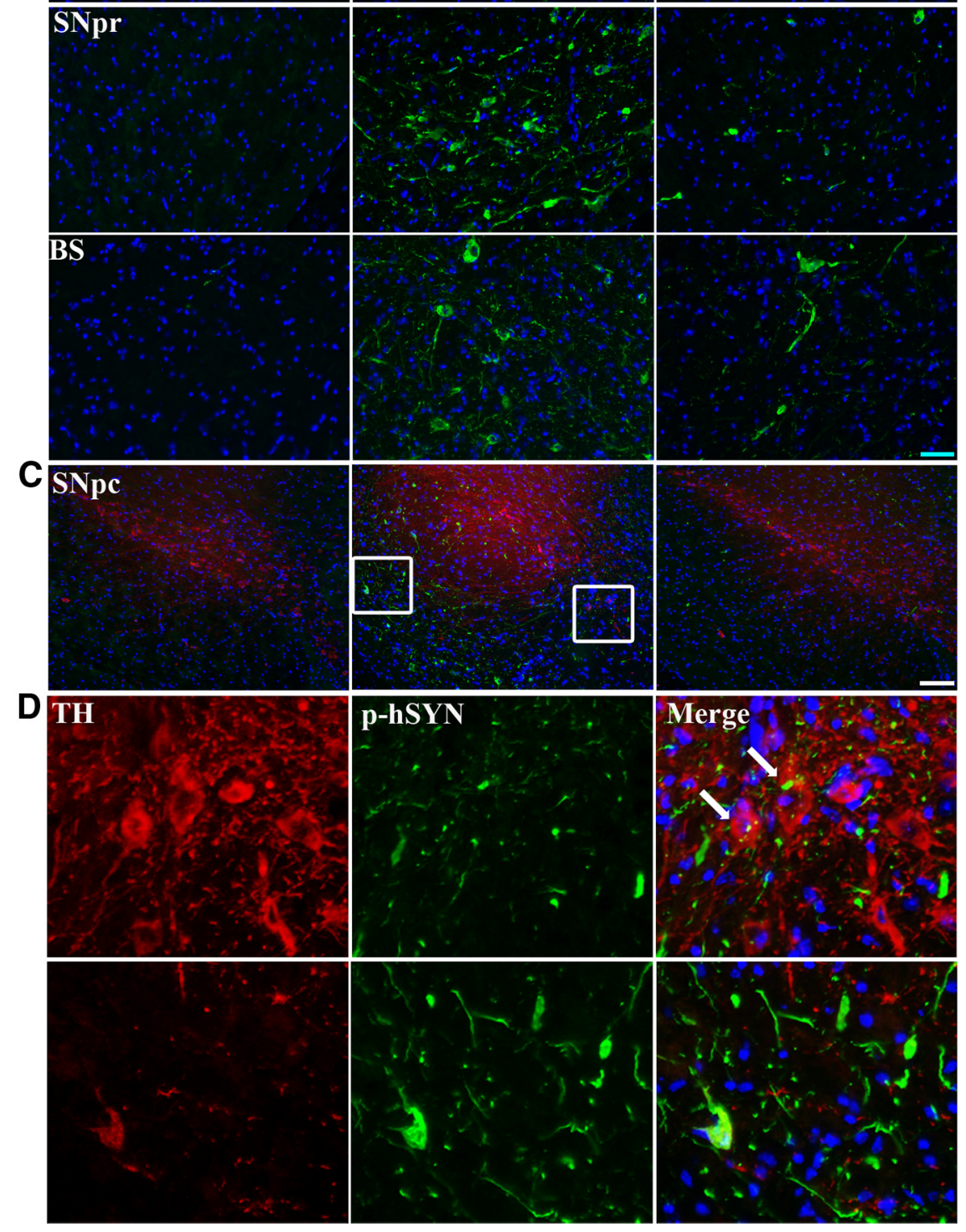

Figure 4. Overexpression of Nrf2 in astrocytes decreases $\mathrm{p}$-hSYN ${ }^{\mathrm{A} 33 \mathrm{~T}}$ aggregates in the brain. Representative fluorescent immunoimages of p-hSYN ${ }^{\text {A53T }}$ (green) with $80 \%$ formic acid pretreatment in different brain areas of 6-month-old asymptomatic, oxygen species (ROS), increased dramatically in symptomatic hSYN ${ }^{\mathrm{A} 53 \mathrm{~T}}$ mice as represented by mRNA levels of its subunits gp91-phox, p47-phox, and p67phox (Fig. 5D). There was also an increased staining density of HNE, a product from lipid peroxidation, especially in neurons in symptomatic hSYN ${ }^{\mathrm{A} 53 \mathrm{~T}}$ mice (Fig. $5 E, F)$. Again, the GFAP-Nrf2 mice $[\mathrm{AN}(+/$ $+)$ ] completely prevented or significantly reduced all of these outcome measures (Fig. $5 A-F)$.

To determine the effect of hSYN ${ }^{\text {A53T }}$ on Nrf2-dependent changes observed in the GFAP-Nrf2 mice, we evaluated mRNA levels of Nrf2 and its regulated genes (Fig. $6 A$ ). Compared with $\mathrm{AN}(-/-)$ or $\mathrm{AN}(+/-)^{*}$ mice, there were dramatic and comparable inductions of Nrf2, NQO1, GCLc, GCLm, and glutathione S-transferase A2 (GSTA2) in the GFAP-Nrf2 $[\mathrm{AN}(-/+)]$ and double transgenic $[\mathrm{AN}$ $(+/+)]$ mice suggesting that the protection of double transgenic mice was due to Nrf2 overexpression (Fig. 6A). Interestingly, GCLm and GCLc decreased significantly in symptomatic hSYN ${ }^{\mathrm{A} 53 \mathrm{~T}}$ mice. These data are in contrast to the 2 - or 6-month-old nonsymptomatic mouse data (Fig. $1 A$ ). In addition, changes in GSH and GSSG were examined in spinal cord (Fig. 6B) and brainstem (Fig. 6C). We have previously published that total GSH (GSH + GSSG) levels are increased by $30-40 \%$ in spinal cord and brainstem of GFAP-Nrf2 mice at 1 month of age (Vargas et al., 2008). These data examined a 6-month-old cohort of mice. In both brainstem and spinal cord there was a trend toward decreased GSH and total GSH in the symptomatic hSYN ${ }^{\mathrm{A} 53 \mathrm{~T}}$ mice $\left[\mathrm{AN}(+/-)^{*}\right.$ vs $\left.\mathrm{AN}(-/-)\right]$. However, the most striking data are the sustained and significant increases of GSH and total GSH in the double transgenic mice $[\mathrm{AN}(+/+)]$ relative to the $\mathrm{hSYN}^{\mathrm{A} 53 \mathrm{~T}}$ mice $\left[\mathrm{AN}(+/-)^{\star}\right]$. GSSG remained relatively unchanged ranging from 3 to $6 \%$ of the total GSH. Thus, the addition of hSYN $^{\text {A53T }}$ did not modulate the ability to activate Nrf2 in the astrocyte or sustain Nrf2-dependent changes in the GFAPNrf2 mice.

$\leftarrow$

symptomatic, and double transgenic mice. $\boldsymbol{A}$, Middle Brain (MB) and brainstem (BS). Scale bar, $1000 \mu \mathrm{m}$. Higher magnification images of the oval and square area are shown in $\boldsymbol{B}$, middle and bottom, respectively. MCX, motor cortex. Blue: Hoechst; $n=3$. Scale bar, $50 \mu \mathrm{m}$. C, Double-labeling of p-hSYN ${ }^{\text {A53T }}$ (green) and TH (red) in SN. Blue: Hoechst. Scale bar, $100 \mu \mathrm{m}$. $\boldsymbol{D}$, Higher magnification images of the square area. Arrows indicate colocalization of p-hSYN ${ }^{\mathrm{A} 53 \mathrm{~T}}$ and TH. 

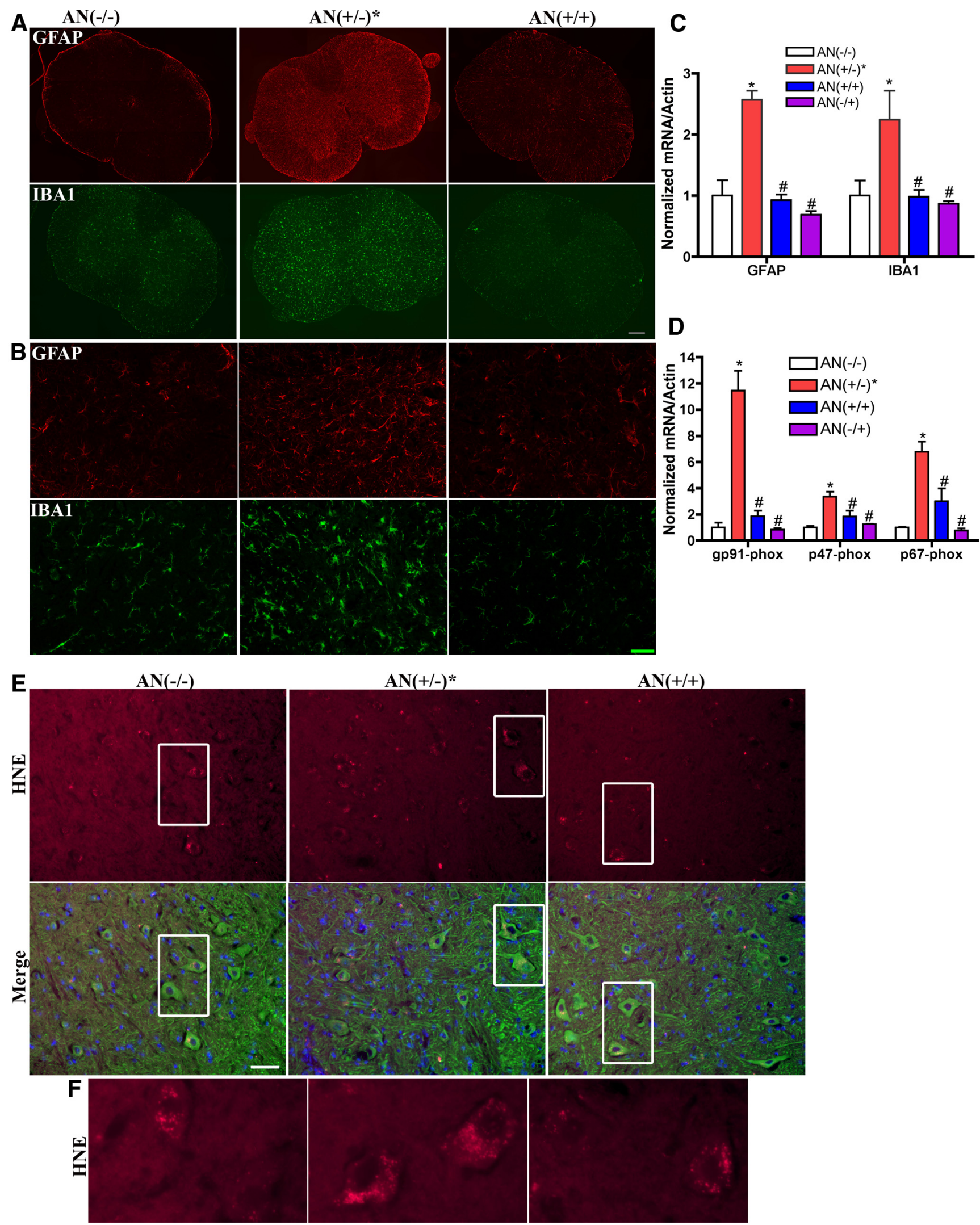

Figure 5. Overexpression of Nrf2 in astrocytes reduces gliosis and oxidative stress in spinal cord. $\boldsymbol{A}$, Fluorescent staining of GFAP (red) and IBA1 (green); $n=3$. Scale bar, $200 \mu \mathrm{m}$. $\boldsymbol{B}$, Representative images of GFAP and IBA 1 in ventral horn with higher magnification. Scale bar, $50 \mu \mathrm{m}$. $C$, mRNA levels of GFAP and IBA1 increased in spinal cord of 6-month-old hSYN ${ }^{A 53}$ mice with symptoms [AN( $\left.\left.+/-\right)^{*}\right]$ compared with wild-type $[\mathrm{AN}(-/-)]$, double transgenic mice $[\mathrm{AN}(+/+)]$, and GFAP-Nrf2 littermates $[\mathrm{AN}(-/+)]$. Mean \pm SEM; $n=4 .{ }^{*} p<0.05, \operatorname{AN}(+/-)^{*}$ versus $\mathrm{AN}(-/-) ; \# p<0.05, \mathrm{AN}(+/+), \mathrm{AN}(-/+)$ versus AN $(+/-)^{*} . D$, mRNA levels of NADPH oxidase subunits gp91-phox, p47-phox, and p67-phoxincreased in spinal cord of 6-month-old hSYN ${ }^{A 53 T}$ mice with symptoms compared with wild-type and double transgenic mice. Mean $\pm \mathrm{SEM} ; n=4 .{ }^{*} p<0.001, \mathrm{AN}(+/-)^{*}$ versus $\mathrm{AN}(-/-) ;{ }^{*} p<0.01, \mathrm{AN}(+/+), \mathrm{AN}(-/+)$ versus $\mathrm{AN}(+/-)^{*}$. E, Intensity of HNE Etaining (red) increased in motorneurons in spinal cord of hSYN ${ }^{A 53 T}$ mice. Green, $\beta$-III-tubulin; blue, Hoechst; $n=3$. Scale bar, $50 \mu \mathrm{m}$. $F$, Higher magnification images of the square areas. 


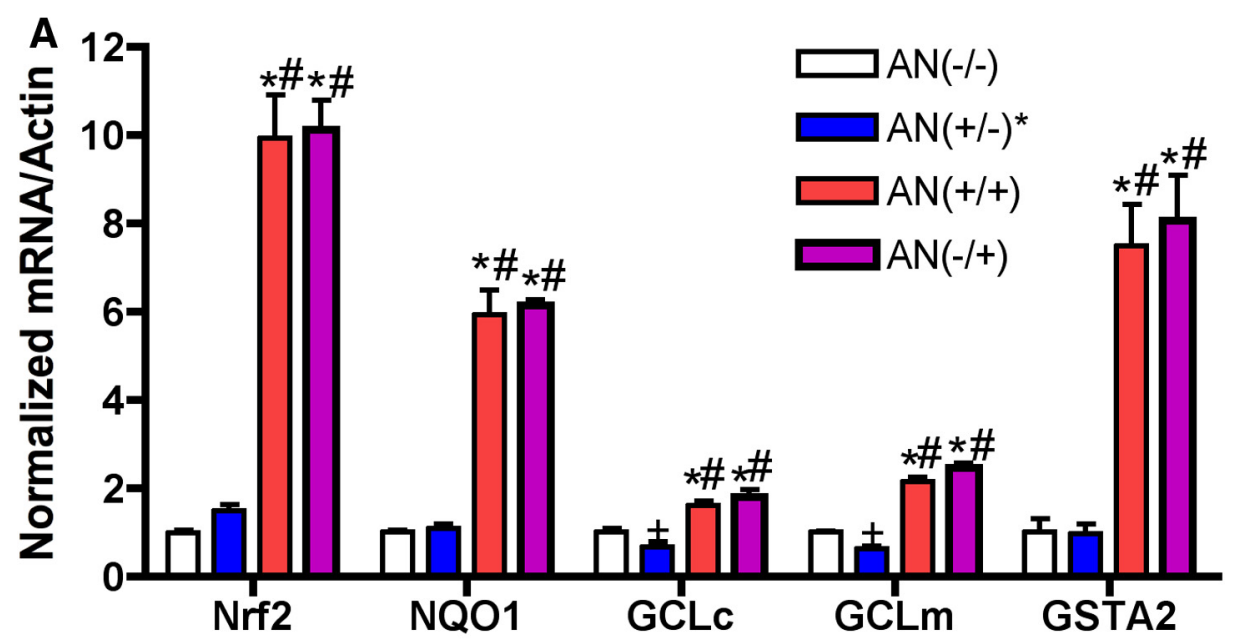

\begin{tabular}{|c|c|c|c|c|c|}
\hline \multirow{2}{*}{$\mathrm{SC}$} & \multicolumn{3}{|c|}{ nmol/mg protein } & \multicolumn{2}{c|}{ Percentage (\%) } \\
\cline { 2 - 6 } & GSH & GSSG & Total & GSH/Total & GSSG/Total \\
\hline $\mathrm{AN}(-/-)$ & $14.0 \pm 1.02$ & $0.73 \pm 0.15$ & $14.8 \pm 1.21$ & $94.7 \pm 0.61$ & $5.33 \pm 0.61$ \\
\hline $\mathrm{AN}(+/-)^{*}$ & $10.7 \pm 1.51$ & $0.44 \pm 0.07$ & $11.1 \pm 1.56$ & $95.9 \pm 0.49$ & $4.10 \pm 0.49$ \\
\hline $\mathrm{AN}(+/+)$ & $18.7 \pm 0.78^{* \#+}$ & $0.64 \pm 0.06$ & $19.4 \pm 0.78^{* \#+}$ & $96.7 \pm 0.30$ & $3.34 \pm 0.30$ \\
\hline $\mathrm{AN}(-/+)$ & $13.9 \pm 1.08$ & $0.95 \pm 0.04$ & $14.9 \pm 1.04$ & $93.5 \pm 0.61$ & $6.52 \pm 0.61$ \\
\hline
\end{tabular}

\begin{tabular}{|c|c|c|c|c|c|}
\hline \multirow{2}{*}{ BS } & \multicolumn{3}{|c|}{ nmol/mg protein } & \multicolumn{2}{c|}{ Percentage (\%) } \\
\cline { 2 - 6 } & GSH & GSSG & Total & GSH/Total & GSSG/Total \\
\hline AN(-/-) & $11.7 \pm 1.65$ & $0.52 \pm 0.36$ & $12.2 \pm 1.73$ & $96.1 \pm 0.36$ & $3.89 \pm 0.36$ \\
\hline AN $(+/-)^{*}$ & $9.19 \pm 1.74$ & $0.42 \pm 0.12$ & $9.6 \pm 1.84$ & $95.8 \pm 0.55$ & $4.18 \pm 0.55$ \\
\hline AN $(+/+)$ & $15.8 \pm 0.20^{*} \#$ & $0.53 \pm 0.06$ & $16.3 \pm 0.18^{*}$ & $96.8 \pm 0.36$ & $3.25 \pm 0.36$ \\
\hline AN(-/+) & $15.1 \pm 2.30$ & $0.72 \pm 0.09$ & $15.8 \pm 2.35$ & $95.2 \pm 0.72$ & $4.80 \pm 0.72$ \\
\hline
\end{tabular}

Figure 6. Overexpression of Nrf2 in astrocytes increases Nrf2-dependent gene expression and GSH levels. $A$, mRNA levels of Nrf2 and its regulated genes in spinal cord of 6-month-old mice from all four genotypes. Mean $\pm \mathrm{SEM} ; n=4 .{ }^{*} p<0.001, \mathrm{AN}(+/+), \mathrm{AN}(-/+)$ versus $\mathrm{AN}(-/-) ;{ }^{\#} p<0.001, \mathrm{AN}(+/+), \mathrm{AN}(-/+)$ versus $\mathrm{AN}(+/-)^{*} ;{ }^{+} p<0.05, \mathrm{AN}(+/-)^{*}$ versus $\mathrm{AN}(-/-)$. Glutathione levels in spinal cord $(\boldsymbol{B})$ and brainstem $(\boldsymbol{C})$ from all four genotypes. Mean $\pm \mathrm{SEM} ; n=3-5 .{ }^{*} p<0.05, \mathrm{AN}(+/+)$ versus $\mathrm{AN}(-/-)$; ${ }^{\#} p<0.05, \mathrm{AN}(+/+)$ versus $\mathrm{AN}(+/-)^{*} ;{ }^{+} p<0.05, \mathrm{AN}(+/+)$ versus $\mathrm{AN}(-/+)$.

CMA is dysfunctional in hSYN ${ }^{\mathrm{A} 53 \mathrm{~T}}$ mice, but not in hSYN $^{\text {A53T }}$ /GFAP-Nrf2 double transgenic mice

MEF2D, a transcription factor involved in neuronal survival, is a substrate of CMA. Inhibition of CMA lead to increased MEF2D levels and accumulation of inactive MEF2D in cytoplasm (Yang et al., 2009). In addition, an increase in MEF2D has been described in a different line of hSYN ${ }^{\text {A53T }}$ mice (Martin et al., 2006). Consistently, we found increased MEF2D (Fig. 7A) and cytoplasmic mislocalization (Fig. $7 B$ ) in the hSYN ${ }^{\text {A53T }}$ line used in our experiments suggesting dysfunctional CMA. There was no change of protein levels for HSC70 and Lamp2a (Fig. 7C,D), while the protein levels of Lamp1, another lysosomal membrane protein, and both the premature and mature forms of lysosomal aspartyl protease cathepsinD (CatD) increased $>4$-fold in symptomatic hSYN ${ }^{\mathrm{A} 53 \mathrm{~T}}$ mice (Fig. $7 C, D$ ). The smeared bands for Lamp1 are indicative of increased Lamp1 glycosylation (Lee et al., 2010). All changes were absent in the double transgenic mice $[\mathrm{AN}(+/+)]$.
Macroautophagy is inhibited in hSYN ${ }^{\mathrm{A} 53 \mathrm{~T}}$ mice, but not in hSYN $^{\text {A53T }}$ /GFAP-Nrf2 double transgenic mice

Macroautophagy includes three main steps: initiation (autophagic complex formation), elongation of phagophores, maturation of autophagosomes, and fusion with lysosomes. LC3 is involved in the last two steps. It is synthesized as a precursor form and is cleaved at its $\mathrm{COOH}$ terminus to form LC3 I in the cytosol. LC3 II is formed by LC3 I conjugation with phosphatidylethanolamine and recruited to the elongating autophagosome membrane. After fusion with the lysosome, LC3 II on the outer membrane will be delipidated and recycled, while inner membrane LC3 II will be degraded in the autolysosome. LC3 II/LC3 I ratio indicates autophagosome formation. The LC3 II/LC3 I ratio was increased in spinal cord lysates from symptomatic hSYN ${ }^{\text {A53T }}$ mice (Fig. 8A). P62 binds with ubiquitinated proteins and protein aggregates, which are trafficked to the autophagosome via p62 association with LC3 II. P62 is also a substrate of macroautophagy. The protein level of p62 increased both in Tritonsoluble and -insoluble fractions from symptomatic hSYN ${ }^{\text {A53T }}$ 
A
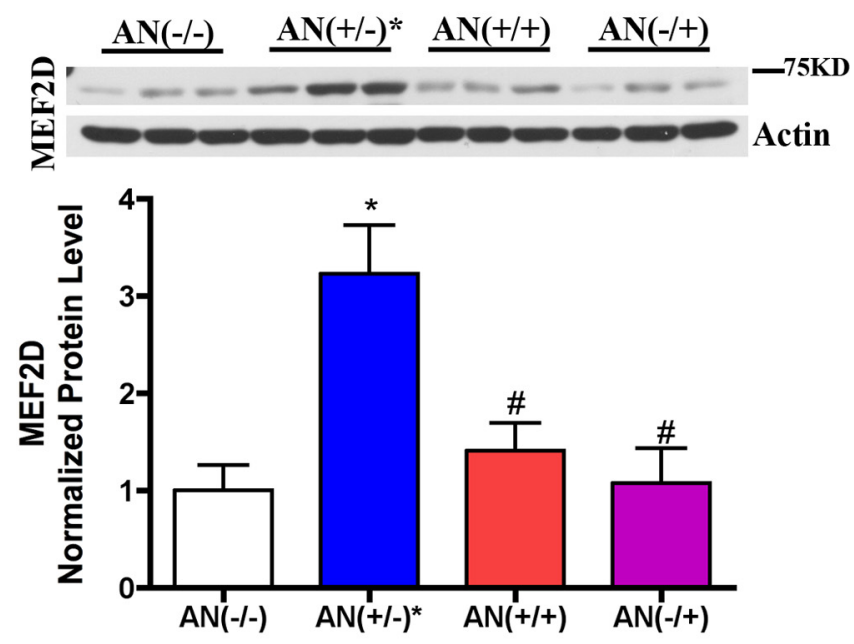

B
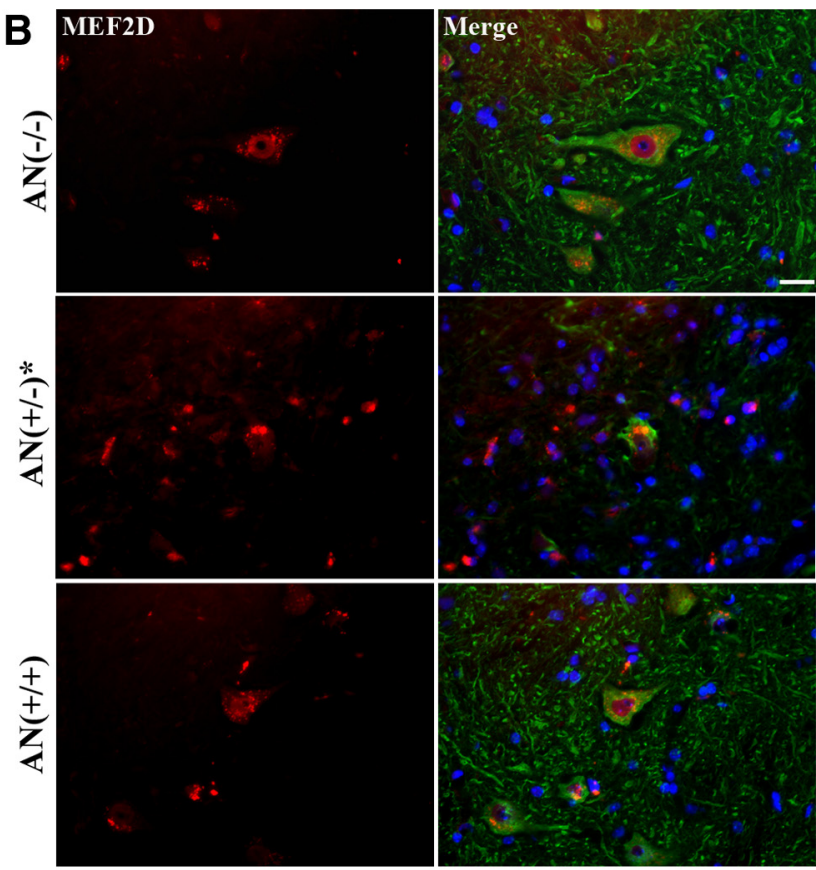

D
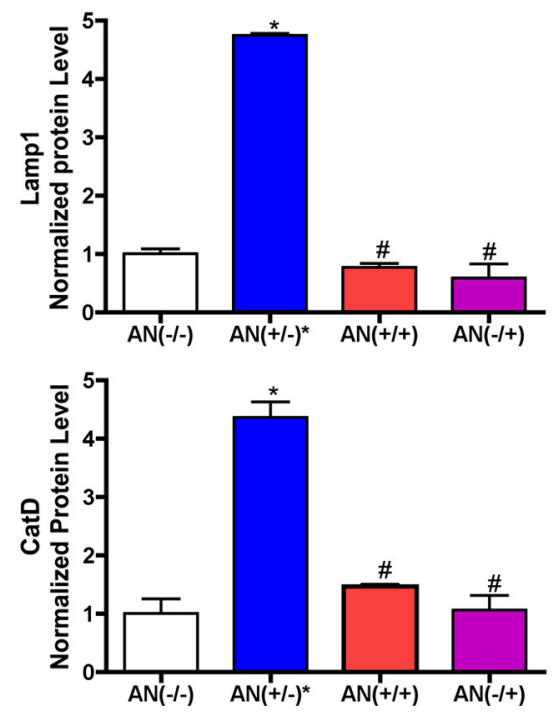

Figure 7. CMA is impaired in hSYN ${ }^{A 53 T}$ mice, not in hSYN ${ }^{A 53 T} / G F A P-N r f 2$ double transgenic mice. $A$, Western blotting for MEF2D from total spinal cord lysates in 6-month-old hSYN ${ }^{A 53 T}$ mice and age-match littermates. Mean $\pm \mathrm{SEM} ; n=3 .{ }^{*} p<0.05, \mathrm{AN}(+/-)^{*}$ versus AN $(-/-) ;{ }^{\#} p<0.01, \mathrm{AN}(+/+), \mathrm{AN}(-/+)$ versus AN $(+/-)^{*}$. B, Fluorescent immunostaining for red, MEF2D; green, $\beta$-III tubulin; and blue, Hoechst; $n=3$. Scale bar, $20 \mu \mathrm{m}$. C, Western blotting for CMA-related chaperone molecular HSC70, lysosomal membrane protein Lamp2a, Lamp1, and lysosomal hydrolase CatD. D, The quantified data for Lamp1, mature CatD (M). Pre, premature CatD. Mean \pm SEM; $n=3 .{ }^{*} p<0.001, \operatorname{AN}(+/-)^{*}$ versus $\operatorname{AN}(-/-) ;{ }^{\#} p<0.001, \operatorname{AN}(+/+), \operatorname{AN}(-/+)$ versus $\mathrm{AN}(+1-)^{*}$.

mice. The smeared pattern of p62 in the Triton-insoluble fractions indicated conjugation and aggregate formation (Fig. $8 B$ ). The increased LC3 II/LC3 I ratio and p62 accumulation in the insoluble fraction demonstrates that there were increased autophagosome vacuoles, but the proteins engulfed inside did not undergo degradation. This speculation was confirmed by colocalization of $\mathrm{p} 62$ and $\mathrm{p}-\mathrm{hSYN} \mathrm{N}^{\mathrm{A} 3 \mathrm{~T}}$ in formic acid pretreated sections (Fig. 8D). Ubiquitin was also slightly increased in the Triton-insoluble fraction in symptomatic hSYN ${ }^{\text {A53T }}$ mice (Fig. $8 C$ ). However, there was no observable histological evidence of ubiquitin accumulation in hSYN ${ }^{\mathrm{A} 53 \mathrm{~T}}$ mice (Fig. $8 E$ ). Ubiquitin staining in hSYN ${ }^{\mathrm{A} 53 \mathrm{~T}}$ mice was diffuse indicating that the p-hSYN ${ }^{\text {A53T }}$ aggregates are p62 positive, but not ubiquitin positive.
Autophagosome-like vacuoles exist in $\mathrm{hSYN}^{\mathrm{A53T}}$ mice, but not hSYN ${ }^{\text {A53T }}$ /GFAP-Nrf2 double transgenic mice In symptomatic hSYN ${ }^{\mathrm{A} 53 \mathrm{~T}}$ mice, neurons with shrunken cell bodies and condensed nuclei were observed compared with neurons with normal morphology in the other three genotypes (Fig. $9 A)$. Lysosomes and lysosome-like structures were rarely observed in the dying neurons of hSYN ${ }^{\mathrm{A} 53 \mathrm{~T}}$ mice compared with variably shaped lysosomes in the other three genotypes. Autophagosome-like structures with double- and multiplelayered membranes existed in the sick neuronal cell bodies and axons in the spinal cord of hSYN ${ }^{\mathrm{A} 53 \mathrm{~T}}$ mice with symptoms, but not in hSYN ${ }^{\mathrm{A} 53 \mathrm{~T}} / \mathrm{GFAP}-\mathrm{Nrf2}$ mice. Few to none autolysosomelike vacuoles with single membranes (autolysosome) were observed in hSYN ${ }^{\text {A53T }}$ mice (Fig. 9B, top and middle); whereas 

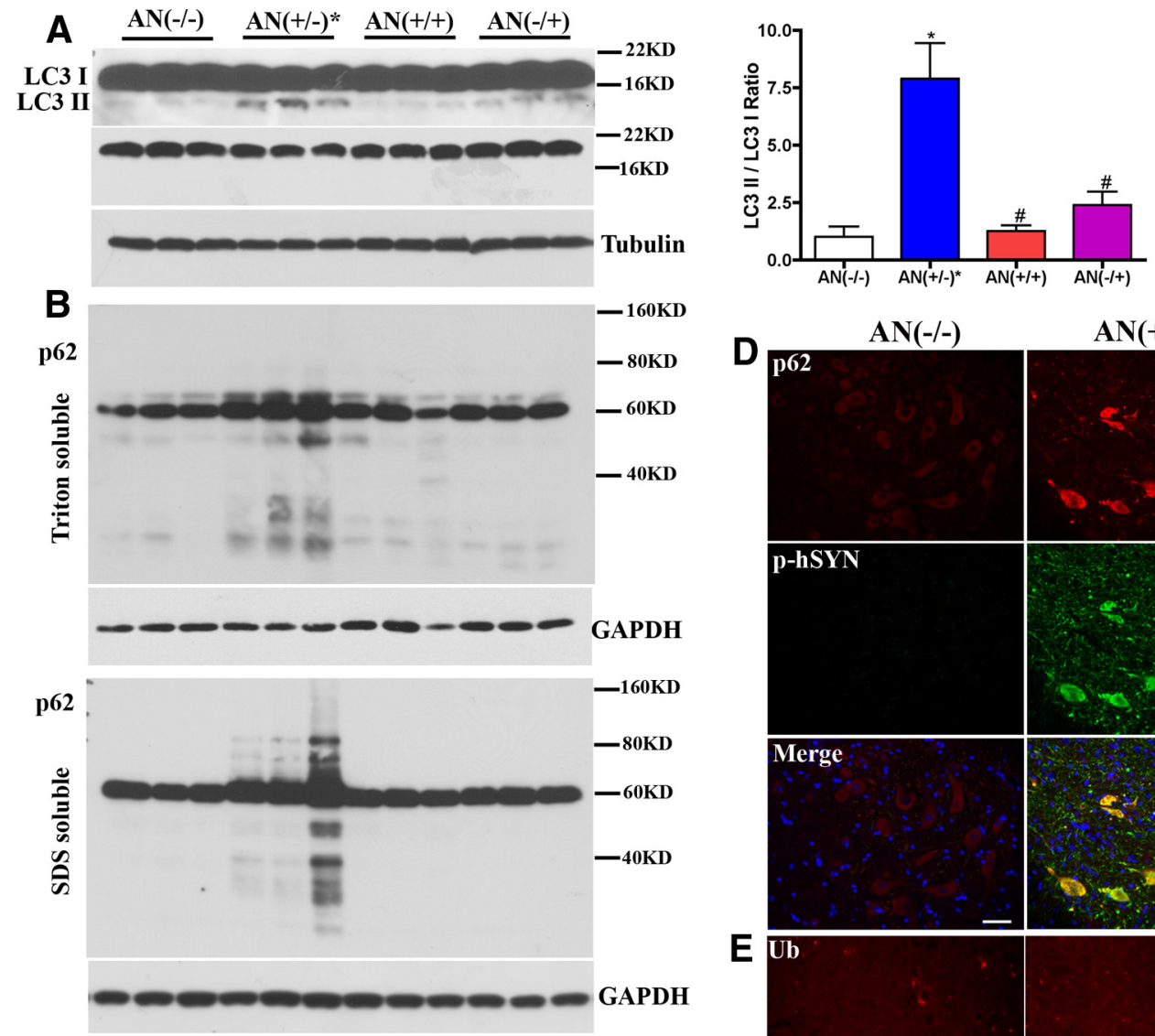

GAPDH
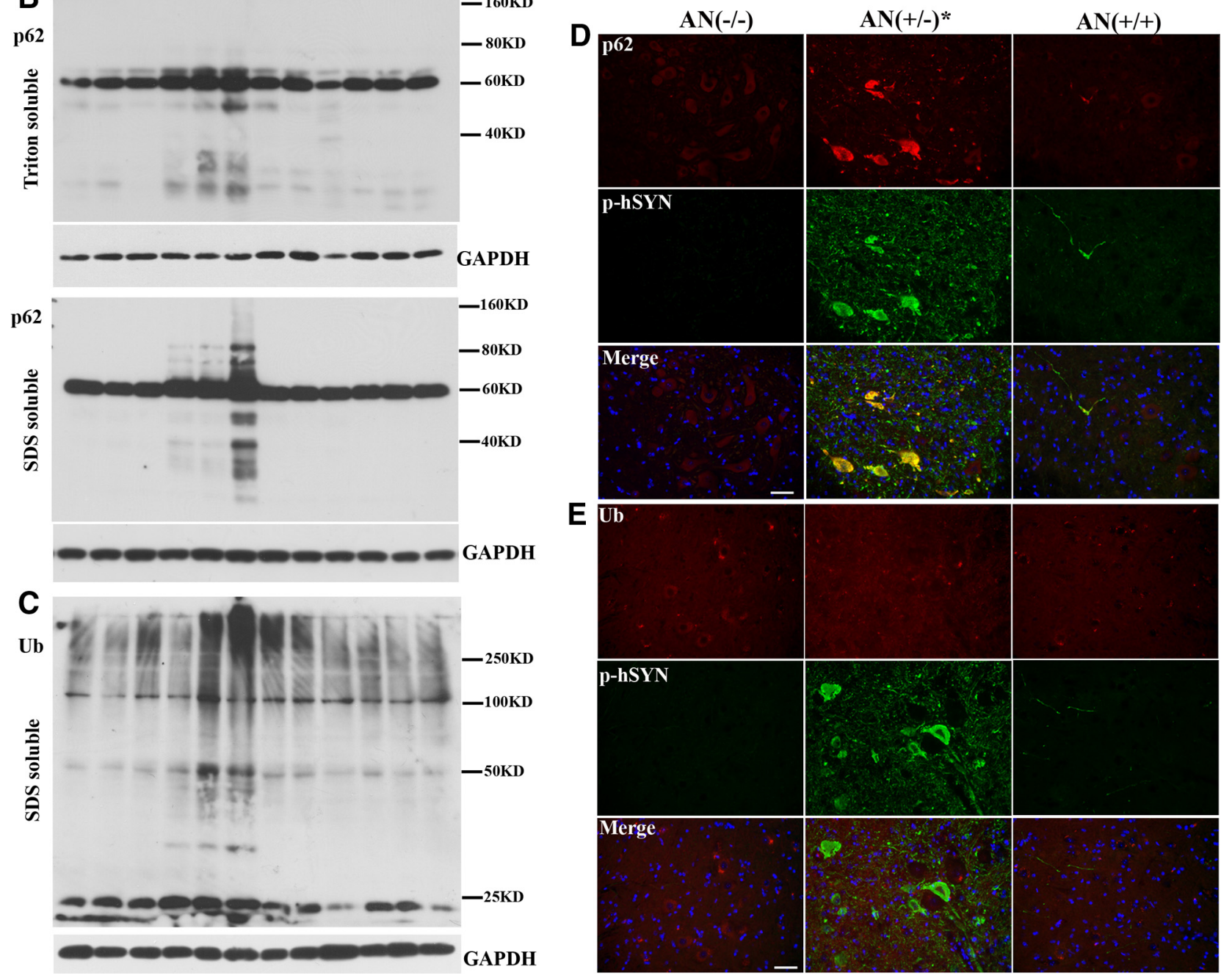

Figure 8. Macroautophagy is dysfunctional in hSYN ${ }^{A 53 T}$ mice, not in hSYN ${ }^{A 53 T} / G F A P-N r f 2$ double transgenic mice. A, Western blots for LC3. Top is overexposed to visualize LC3 II. A shorter exposure to quantify $L C 3$ I is next. The quantification of $L C 3 \mathrm{II} / \mathrm{LC} 3$ I ratio is shown on the left. Mean $\pm \mathrm{SEM} ; n=3 .{ }^{*} p<0.01, \mathrm{AN}(+/-)^{*}$ versus $\operatorname{AN}(-/-) ;{ }^{\#} p<0.01, \operatorname{AN}(+/+), \operatorname{AN}(-/+)$ versus $\mathrm{AN}(+/-)^{*}$. $\boldsymbol{B}$, Western blotting of p62. Top, Triton-soluble fractions; bottom, Triton-insoluble fractions; $n=3$. C, Western blotting of ubiquitin in Triton-insoluble fractions. Ub, ubiquitin; $n=3$. Representative images for $\mathrm{p}-\mathrm{hSYN}{ }^{\mathrm{A} 33 \mathrm{~T}}$ and p62 (D) or Ub (E) colocalization; $n=3$. Scale bars: $50 \mu \mathrm{m}$.

numerous residual bodies of lysosomes were present in the double transgenic mice (Fig. 9C). Finally, there was an intermediate neuronal phenotype in hSYN ${ }^{\mathrm{A} 53 \mathrm{~T}}$ mice that contained both vacuolated lysosomes along with normal lysosomes (Fig. 9B, bottom).

\section{Discussion}

SYN is the first gene that was identified in PD patients and is the main component in Lewy bodies. It is believed that SYN is a central player in the pathology of $\mathrm{PD}$ and other $\alpha$-synucleinopathies.

The Nrf2-ARE pathway regulates a cell defense system to fight against oxidative insults. Overexpression of Nrf2 in astrocytes delayed the pathology of hSYN ${ }^{\text {A53T }}$ mice and reduced Triton-

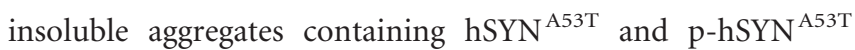
(Figs. 2-4). The autophagy-lysosome pathway is a highly conserved bulk protein degradation system responsible for the turnover of long-lived proteins, clearance of aggregate-prone proteins, and disposal of damaged organelles. Inactivation of autophagy results in cytoplasmic protein inclusions composed of misfolded proteins and deformed organelles, which could lead to neurodegeneration and other diseases. The level of autophagosome-associated LC3 II or the ratio of LC3 II to LC3 I has been used to evaluate macroautophagy. LC3 II is a substrate of macroautophagy, and the level of LC3 II alone is correlated with the number of phagophores/autophagosomes instead of induction of autophagy (Klionsky et al., 2008). The accumulation of 

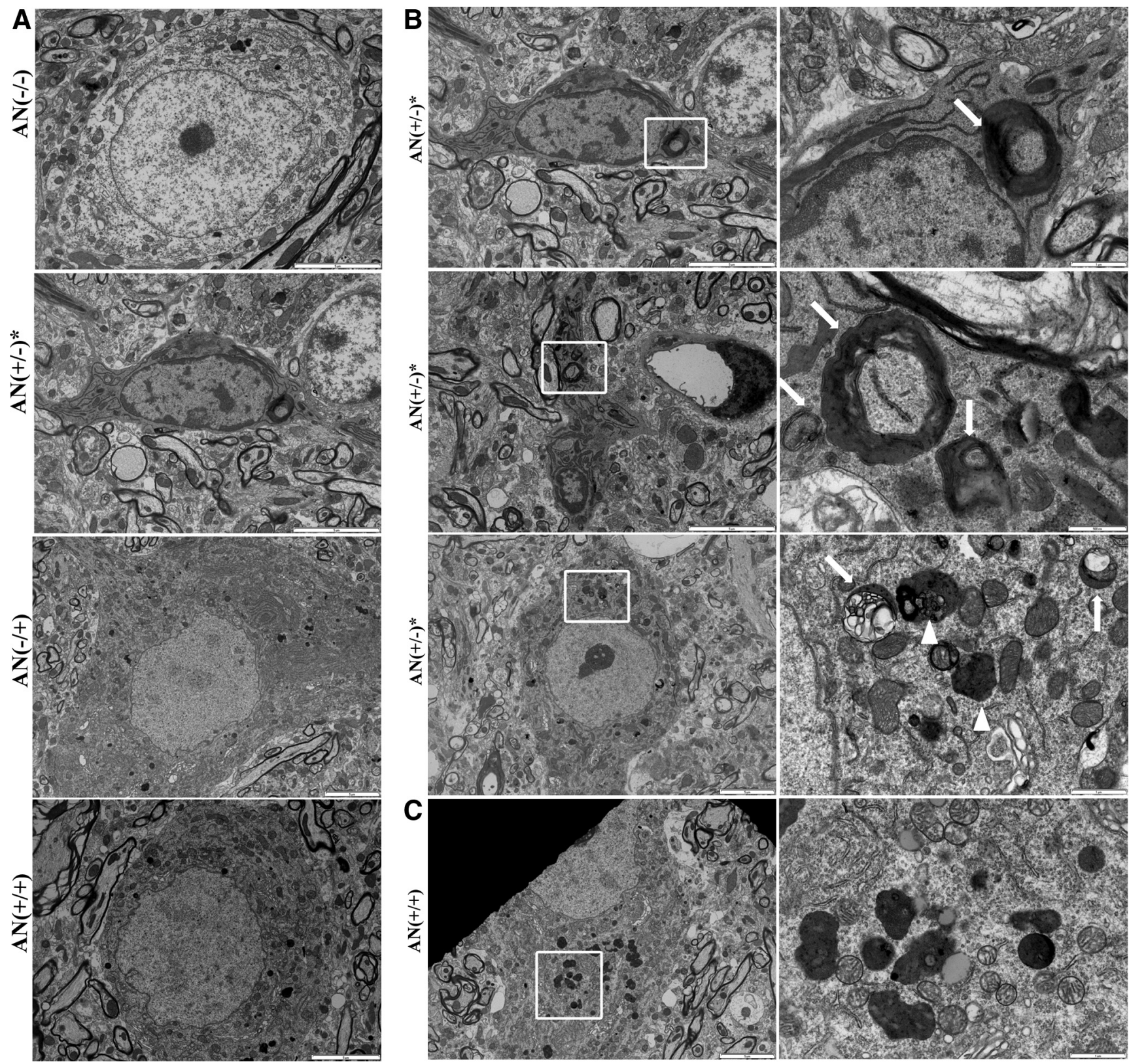

Figure 9. Autophagosome-like vacuoles exist in hSYN ${ }^{A 53 T}$ mice, not hSYN ${ }^{A 53 T} /$ GFAP-Nrf2 double transgenic mice. A, Electron microscopic (EM) images of motor neurons in lumbar spinal cord from 8-month-old hSYN ${ }^{A 53 T}$ mice, hSYN ${ }^{A 53 T} / G F A P-N r f 2$ mice, and littermate controls. $B$, Top and middle, autophagosome-like vacuoles in cell body and axon of neurons from hSYN ${ }^{A 53 T}$ mouse with symptoms. Scale bars: $5 \mu \mathrm{m}$. Higher magnification images of the square areas are shown on the right. Scale bars: $1 \mu \mathrm{m}$ (top) and $500 \mathrm{~nm}$ (middle). Arrows denote the vacuoles. Bottom, A healthier looking neuron from hSYN ${ }^{\text {A53T }}$ mouse with vacuolated (arrows) and normal (arrowheads) lysosomes. Scale bars: $5 \mu \mathrm{m}$ (left) and $1 \mu \mathrm{m}$ (right). C, EM images for hSYN ${ }^{\text {A53T } / G F A P-N r f 2 ~ m o u s e . ~ H i g h e r ~}$ magnification images of the square areas are shown on the right. Scale bars: $5 \mu \mathrm{m}$ (left) and $1 \mu \mathrm{m}$ (right).

p62, another substrate of macroautophagy, confirmed a dysregulation of macroautophagy. Colocalization of $\mathrm{p} 62$ and $\mathrm{p}-\mathrm{hSYN}{ }^{\mathrm{A} 53 \mathrm{~T}}$ suggested that p62 and p-hSYN ${ }^{\mathrm{A} 53 \mathrm{~T}}$ were both localized in aggregates. Increased autophagosome formation could be due to increased autophagic activity or reduced turnover of autophagosomes. This study supports that failed turnover is the cause. Observation of autophagic vacuoles with electronic microscopy is another standard way to monitor autophagy. Autophagosome-like structures not autolysosome-like vacuoles were observed in hSYN ${ }^{\mathrm{A} 53 \mathrm{~T}}$ mice. All these data confirmed that early autophagy was activated, but the fusion step of autophagy with the lysosome did not proceed.

It is interesting that there was no obvious increase of ubiquitin accumulation, or colocalization of $\mathrm{p}-\mathrm{hSYN} \mathrm{N}^{\mathrm{A} 53 \mathrm{~T}}$ and ubiquitin.
There are two possibilities. First, hSYN ${ }^{\mathrm{A} 53 \mathrm{~T}}$ and p62 could be conjugated together for degradation through ubiquitinindependent macroautophagy. Existing evidence shows that ubiquitinated SYN/p-SYN is not always observed and is not necessary for formation of pathological inclusions or degradation (Liu et al., 2003; Sampathu et al., 2003; Machiya et al., 2010; Ebrahimi-Fakhari et al., 2011). A recent report points out that mono-ubiquitinated SYN is degraded by the UPS and deubiquitinated SYN is mainly degraded by ALP (Rott et al., 2011). Additionally, p62 could mediate ALP clearance of nonubiquitinated substrates in an HDAC6-dependent manner (Watanabe and Tanaka, 2011) suggesting that clearance of SYN/p-SYN could occur via a p62-dependent but ubiquitin-independent mecha- 
nism. Second, both p-hSYN ${ }^{\mathrm{A} 53 \mathrm{~T}}$ and p62 could be trapped in vacuoles as separate misfolded proteins. As substrates of macroautophagy, SYN, and $\mathrm{p} 62$ may be accumulated together without physical interaction when macroautophagy is dysregulated.

CatD is a soluble lysosomal aspartic endopeptidase. It functions in the lysosome to cleave SYN. The exact outcome of this function is very controversial. Overexpression of CatD prevented SYN aggregation and toxicity in vitro and in a Caenorhabditis elegans model (Qiao et al., 2008). Our data show that there was a dramatic induction of premature and mature CatD that correlates with the formation of aggregates. These observations are consistent with previously published data that phosphorylated SYN induces upregulation of casin kinase 2 and CatD (Takahashi et al., 2007). Inhibition of autophagy could also induce CatDmediated apoptotic cell death (Carew et al., 2011). $\mathrm{H}_{2} \mathrm{O}_{2}$-induced ROS production and endothelial cell apoptosis can be enhanced by CatD overexpression and suppressed by knockdown of CatD (Haendeler et al., 2005). CatD acts as a death executor beyond caspase 3. The CatD death pathway is upstream of or independent of caspase cascades, and autophagosomes appear before DNA fragmentation in vitro (Deiss et al., 1996; Isahara et al., 1999; Kågedal et al., 2001). We observed shrunken cell bodies and condensed nuclear chromatin with electronic microscopy, but could not detect any cleaved caspase 3 by Western blotting (data not shown). These results suggest a CatD-mediated motor neuron loss in hSYN ${ }^{\mathrm{A} 53 \mathrm{~T}}$ mice.

Together, overexpression of hSYN ${ }^{\mathrm{A} 33 \mathrm{~T}}$ negatively affected protein clearance pathways including CMA and macroautophagy. This leads us to hypothesize that the increased oxidative stress associated with incomplete degradation of aggregates caused an abnormal modification of lysosome membrane protein Lamp1, and increased permeabilization of the lysosomal membrane (Lee et al., 2010) resulting in lysosomal protease CatD-mediated cell death. The question remains as to how Nrf2 in astrocytes can protect neurons from $\mathrm{hSYN}{ }^{\mathrm{A} 53 \mathrm{~T}}$-mediated toxicity. The GSH system was negatively affected in symptomatic hSYN ${ }^{\text {A53T }}$ mice, whereas increases in GCLc, GCLm, and total GSH were observed in spinal cord of double transgenic mice (Fig. 6). Perhaps overexpression of Nrf2 in astrocytes through secretion of glutathione and other antioxidant proteins could increase the ability of the neurons to combat oxidative stress thereby allowing for maintaining normal function of ALP and hSYN ${ }^{\mathrm{A53T}}$ clearance. The data herein and an earlier publication in mouse models of amyotrophic lateral sclerosis (Vargas et al., 2008) provide support for this hypothesis. Alternatively, changes in UPS could also contribute, but we have not seen any change in proteasome activity in the GFAP-Nrf2 mice (data not shown). It is also possible that secreted SYN is taken up and degraded by the Nrf2 astrocytes; however, immunohistochemical double labeling of hSYN ${ }^{\mathrm{A53T}}$ and $\mathrm{p}-\mathrm{hSYN}{ }^{\mathrm{A} 53 \mathrm{~T}}$ with the astrocyte marker GFAP showed no overlap (data not shown).

A major issue in PD research is the lack of an effective genetic mouse model that develops progressive degeneration of dopaminergic neurons (Hisahara and Shimohama, 2010). This includes the SYN mouse models that primarily develop symptoms of motor neuron diseases (Giasson et al., 2002; Martin et al., 2006). A new SYN line, using the tetracycline inducible system, has been developed and shows progressive dopaminergic neuron degeneration by overexpression of $\mathrm{hSYN}^{\mathrm{A} 53 \mathrm{~T}}$ selectively in dopaminergic neurons (Lin et al., 2012). Determining how Nrf2 modulated dopaminergic pathology in this mouse line may be more relevant to PD. However, this does not dampen the dramatic ability and relevance of Nrf2 to modulate SYN pathology. Indeed, more and more clinical data demonstrate that SYN and p-SYN-positive inclusions exist in the brainstem and spinal cord in asymptomatic (incidental Lewy body disease) and/or sporadic PD patients (Braak et al., 2003; Del Tredici and Braak, 2012; Tamura et al., 2012). Thus, understanding the mechanism as to how Nrf2 overexpressing astrocytes confer protection to neurons overexpressing hSYN ${ }^{\mathrm{A} 3 \mathrm{~T}}$ is the current focus of our ongoing experiments. Overall, activation of the Nrf2 pathway in astrocytes is a potential target to develop therapeutic strategies for treating pathological synucleinopathies including PD.

\section{References}

Anderson JP, Walker DE, Goldstein JM, de Laat R, Banducci K, Caccavello RJ, Barbour R, Huang J, Kling K, Lee M, Diep L, Keim PS, Shen X, Chataway T, Schlossmacher MG, Seubert P, Schenk D, Sinha S, Gai WP, Chilcote TJ (2006) Phosphorylation of Ser-129 is the dominant pathological modification of alpha-synuclein in familial and sporadic Lewy body disease. J Biol Chem 281:29739-29752. CrossRef Medline

Barone MC, Sykiotis GP, Bohmann D (2011) Genetic activation of Nrf2 signaling is sufficient to ameliorate neurodegenerative phenotypes in a Drosophila model of Parkinson's disease. Dis Model Mech 4:701-707. CrossRef Medline

Braak H, Del Tredici K, Rüb U, de Vos RA, Jansen Steur EN, Braak E (2003) Staging of brain pathology related to sporadic Parkinson's disease. Neurobiol Aging 24:197-211. CrossRef Medline

Calkins MJ, Vargas MR, Johnson DA, Johnson JA (2010) Astrocyte-specific overexpression of $\mathrm{Nrf2}$ protects striatal neurons from mitochondrial complex II inhibition. Toxicol Sci 115:557-568. CrossRef Medline

Carew JS, Espitia CM, Esquivel JA 2nd, Mahalingam D, Kelly KR, Reddy G, Giles FJ, Nawrocki ST (2011) Lucanthone is a novel inhibitor of autophagy that induces cathepsin D-mediated apoptosis. J Biol Chem 286: 6602-6613. CrossRef Medline

Chandra S, Gallardo G, Fernández-Chacón R, Schlüter OM, Südhof TC (2005) Alpha-synuclein cooperates with CSPalpha in preventing neurodegeneration. Cell 123:383-396. CrossRef Medline

Chen PC, Vargas MR, Pani AK, Smeyne RJ, Johnson DA, Kan YW, Johnson JA (2009) Nrf2-mediated neuroprotection in the MPTP mouse model of Parkinson's disease: critical role for the astrocyte. Proc Natl Acad Sci U S A 106:2933-2938. CrossRef Medline

Chew KC, Ang ET, Tai YK, Tsang F, Lo SQ, Ong E, Ong WY, Shen HM, Lim KL, Dawson VL, Dawson TM, Soong TW (2011) Enhanced autophagy from chronic toxicity of iron and mutant A53T alpha-synuclein: implications for neuronal cell death in Parkinson disease. J Biol Chem 286: 33380-33389. CrossRef Medline

Cuervo AM, Stefanis L, Fredenburg R, Lansbury PT, Sulzer D (2004) Impaired degradation of mutant alpha-synuclein by chaperone-mediated autophagy. Science 305:1292-1295. CrossRef Medline

Deiss LP, Galinka H, Berissi H, Cohen O, Kimchi A (1996) Cathepsin D protease mediates programmed cell death induced by interferon-gamma, Fas/APO-1 and TNF-alpha. EMBO J 15:3861-3870. Medline

Del Tredici K, Braak H (2012) Spinal cord lesions in sporadic Parkinson's disease. Acta Neuropathol 124:643-664. CrossRef Medline

Ebrahimi-Fakhari D, Cantuti-Castelvetri I, Fan Z, Rockenstein E, Masliah E, Hyman BT, McLean PJ, Unni VK (2011) Distinct roles in vivo for the ubiquitin-proteasome system and the autophagy-lysosomal pathway in the degradation of alpha-synuclein. J Neurosci 31:14508-14520. CrossRef Medline

Fariss MW, Reed DJ (1987) High-performance liquid chromatography of thiols and disulfides: dinitrophenol derivatives. Methods Enzymol 143: 101-109. CrossRef Medline

Fernagut PO, Chesselet MF (2004) Alpha-synuclein and transgenic mouse models. Neurobiol Dis 17:123-130. CrossRef Medline

Fujiwara H, Hasegawa M, Dohmae N, Kawashima A, Masliah E, Goldberg MS, Shen J, Takio K, Iwatsubo T (2002) alpha-Synuclein is phosphorylated in synucleinopathy lesions. Nat Cell Biol 4:160-164. Medline

Gallardo G, Schlüter OM, Südhof TC (2008) A molecular pathway of neurodegeneration linking alpha-synuclein to ApoE and Abeta peptides. Nat Neurosci 11:301-308. CrossRef Medline

Gan L, Johnson DA, Johnson JA (2010) Keap1-Nrf2 activation in the presence and absence of DJ-1. Eur J Neurosci 31:967-977. CrossRef Medline Giasson BI, Duda JE, Quinn SM, Zhang B, Trojanowski JQ, Lee VM (2002) 
Neuronal alpha-synucleinopathy with severe movement disorder in mice expressing A53T human alpha-synuclein. Neuron 34:521-533. CrossRef Medline

Haendeler J, Popp R, Goy C, Tischler V, Zeiher AM, Dimmeler S (2005) Cathepsin D and $\mathrm{H} 2 \mathrm{O} 2$ stimulate degradation of thioredoxin-1: implication for endothelial cell apoptosis. J Biol Chem 280:42945-42951. CrossRef Medline

Hisahara S, Shimohama S (2010) Toxin-induced and genetic animal models of Parkinson's disease. Parkinsons Dis 2011:951709. Medline

Honegger KJ, Capuano P, Winter C, Bacic D, Stange G, Wagner CA, Biber J, Murer H, Hernando N (2006) Regulation of sodium-proton exchanger isoform 3 (NHE3) by PKA and exchange protein directly activated by cAMP (EPAC). Proc Natl Acad Sci U S A 103:803-808. CrossRef Medline Irizarry MC, Growdon W, Gomez-Isla T, Newell K, George JM, Clayton DF, Hyman BT (1998) Nigral and cortical Lewy bodies and dystrophic nigral neurites in Parkinson's disease and cortical Lewy body disease contain alpha-synuclein immunoreactivity. J Neuropathol Exp Neurol 57: 334-337. CrossRef Medline

Isahara K, Ohsawa Y, Kanamori S, Shibata M, Waguri S, Sato N, Gotow T, Watanabe T, Momoi T, Urase K, Kominami E, Uchiyama Y (1999) Regulation of a novel pathway for cell death by lysosomal aspartic and cysteine proteinases. Neuroscience 91:233-249. CrossRef Medline

Itoh K, Chiba T, Takahashi S, Ishii T, Igarashi K, Katoh Y, Oyake T, Hayashi N, Satoh K, Hatayama I, Yamamoto M, Nabeshima Y (1997) An Nrf2/ small Maf heterodimer mediates the induction of phase II detoxifying enzyme genes through antioxidant response elements. Biochem Biophys Res Commun 236:313-322. CrossRef Medline

Johnson DA, Andrews GK, Xu W, Johnson JA (2002) Activation of the antioxidant response element in primary cortical neuronal cultures derived from transgenic reporter mice. J Neurochem 81:1233-1241. CrossRef Medline

Johnson DA, Amirahmadi S, Ward C, Fabry Z, Johnson JA (2010) The absence of the pro-antioxidant transcription factor Nrf2 exacerbates experimental autoimmune encephalomyelitis. Toxicol Sci 114:237-246.

Kågedal K, Johansson U, Ollinger K (2001) The lysosomal protease cathepsin D mediates apoptosis induced by oxidative stress. FASEB J 15:15921594. Medline

Klionsky DJ, et al. (2008) Guidelines for the use and interpretation of assays for monitoring autophagy in higher eukaryotes. Autophagy 4:151-175. Medline

Krüger R, Kuhn W, Müller T, Woitalla D, Graeber M, Kösel S, Przuntek H, Epplen JT, Schöls L, Riess O (1998) AlaSOPro mutation in the gene encoding alpha-synuclein in Parkinson's disease. Nat Genet 18:106-108. CrossRef Medline

Lastres-Becker I, Ulusoy A, Innamorato NG, Sahin G, Rábano A, Kirik D, Cuadrado A (2012) alpha-Synuclein expression and Nrf2 deficiency cooperate to aggravate protein aggregation, neuronal death and inflammation in early stage Parkinson's disease. Hum Mol Genet 21:3173-3192. CrossRef Medline

Lee SJ, Park MH, Kim HJ, Koh JY (2010) Metallothionein-3 regulates lysosomal function in cultured astrocytes under both normal and oxidative conditions. Glia 58:1186-1196. Medline

Lin X, Parisiadou L, Sgobio C, Liu G, Yu J, Sun L, Shim H, Gu XL, Luo J, Long CX, Ding J, Mateo Y, Sullivan PH, Wu LG, Goldstein DS, Lovinger D, Cai H (2012) Conditional expression of parkinson's disease-related mutant alpha-synuclein in the midbrain dopaminergic neurons causes progressive neurodegeneration and degradation of transcription factor nuclear receptor related 1. J Neurosci 32:9248-9264. CrossRef Medline

Liu CW, Corboy MJ, DeMartino GN, Thomas PJ (2003) Endoproteolytic activity of the proteasome. Science 299:408-411. CrossRef Medline

Machiya Y, Hara S, Arawaka S, Fukushima S, Sato H, Sakamoto M, Koyama S, Kato T (2010) Phosphorylated alpha-synuclein at Ser-129 is targeted to the proteasome pathway in a ubiquitin-independent manner. J Biol Chem 285:40732-40744. CrossRef Medline

Martin LJ, Pan Y, Price AC, Sterling W, Copeland NG, Jenkins NA, Price DL, Lee MK (2006) Parkinson's disease alpha-synuclein transgenic mice develop neuronal mitochondrial degeneration and cell death. J Neurosci 26:41-50. CrossRef Medline

Motohashi H, O'Connor T, Katsuoka F, Engel JD, Yamamoto M (2002) Integration and diversity of the regulatory network composed of Maf and CNC families of transcription factors. Gene 294:1-12. CrossRef Medline

Polymeropoulos MH, Lavedan C, Leroy E, Ide SE, Dehejia A, Dutra A, Pike B, Root H, Rubenstein J, Boyer R, Stenroos ES, Chandrasekharappa S, Athanassiadou A, Papapetropoulos T, Johnson WG, Lazzarini AM, Duvoisin RC, Di Iorio G, Golbe LI, Nussbaum RL (1997) Mutation in the alphasynuclein gene identified in families with Parkinson's disease. Science 276:2045-2047. CrossRef Medline

Qiao L, et al. (2008) Lysosomal enzyme cathepsin D protects against alphasynuclein aggregation and toxicity. Mol Brain 1:17. CrossRef Medline

Rott R, Szargel R, Haskin J, Bandopadhyay R, Lees AJ, Shani V, Engelender S (2011) alpha-Synuclein fate is determined by USP9X-regulated monoubiquitination. Proc Natl Acad Sci U S A 108:18666-18671. CrossRef Medline

Sampathu DM, Giasson BI, Pawlyk AC, Trojanowski JQ, Lee VM (2003) Ubiquitination of alpha-synuclein is not required for formation of pathological inclusions in alpha-synucleinopathies. Am J Pathol 163:91-100. CrossRef Medline

Singleton AB, et al. (2003) alpha-Synuclein locus triplication causes Parkinson's disease. Science 302:841. CrossRef Medline

Spillantini MG, Schmidt ML, Lee VM, Trojanowski JQ, Jakes R, Goedert M (1997) Alpha-synuclein in Lewy bodies. Nature 388:839-840. CrossRef Medline

Takahashi M, Ko LW, Kulathingal J, Jiang P, Sevlever D, Yen SH (2007) Oxidative stress-induced phosphorylation, degradation and aggregation of alpha-synuclein are linked to upregulated CK2 and cathepsin D. Eur J Neurosci 26:863-874. CrossRef Medline

Tamura T, Yoshida M, Hashizume Y, Sobue G (2012) Lewy body-related alpha-synucleinopathy in the spinal cord of cases with incidental Lewy body disease. Neuropathology 32:13-22. CrossRef Medline

van der Putten H, Wiederhold KH, Probst A, Barbieri S, Mistl C, Danner S, Kauffmann S, Hofele K, Spooren WP, Ruegg MA, Lin S, Caroni P, Sommer B, Tolnay M, Bilbe G (2000) Neuropathology in mice expressing human alpha-synuclein. J Neurosci 20:6021-6029. Medline

Vargas MR, Johnson DA, Sirkis DW, Messing A, Johnson JA (2008) Nrf2 activation in astrocytes protects against neurodegeneration in mouse models of familial amyotrophic lateral sclerosis. J Neurosci 28: 13574-13581. CrossRef Medline

Vogiatzi T, Xilouri M, Vekrellis K, Stefanis L (2008) Wild type alphasynuclein is degraded by chaperone-mediated autophagy and macroautophagy in neuronal cells. J Biol Chem 283:23542-23556. CrossRef Medline

Watanabe Y, Tanaka M (2011) p62/SQSTM1 in autophagic clearance of a non-ubiquitylated substrate. J Cell Sci 124:2692-2701. CrossRef Medline

Winslow AR, Chen CW, Corrochano S, Acevedo-Arozena A, Gordon DE, Peden AA, Lichtenberg M, Menzies FM, Ravikumar B, Imarisio S, Brown S, O'Kane CJ, Rubinsztein DC (2010) alpha-Synuclein impairs macroautophagy: implications for Parkinson's disease. J Cell Biol 190:10231037. CrossRef Medline

Yang Q, She H, Gearing M, Colla E, Lee M, Shacka JJ, Mao Z (2009) Regulation of neuronal survival factor MEF2D by chaperone-mediated autophagy. Science 323:124-127. CrossRef Medline

Zheng L, Kågedal K, Dehvari N, Benedikz E, Cowburn R, Marcusson J, Terman A (2009) Oxidative stress induces macroautophagy of amyloid beta-protein and ensuing apoptosis. Free Radic Biol Med 46:422-429. CrossRef Medline 